\title{
Durability of Double-Shell Slurry Feed Grouts: FY-90 Results
}

\author{
R. O. Lokken \\ P. F. C. Martin
}

December 1992

RECEIVED

Prepared for the U.S. Department of Energy under Contract DE-AC06-76RLO 1830

Pacific Northwest Laboratory

Operated for the U.S. Department of Energy

by Battelle Memorial Institute 


\section{DISCLAIMER}

This report was prepared as an account of work sponsored by an agency of the United States Government. Neither the United States Government nor any agency thereof, nor Batteile Memorial Institute, nor any of their employees, makes any warranty, expressed or implied, or assumes any legal liability or responsibility for the accuracy, completeness, or usefulness of any information, apparatus, product, or process disclosed, or represents that its use would not infringe privately owned rights. Reference herein to any specific commercial product, process, or service by trade name, trademark, manufacturer, or otherwise does not necessarily constitute or imply its endorsement, recommendation, or favoring by the United States Government or any agency thereof, or Battelle Memorial Institute. The views and opinions of authors expressed herein do not necessarily state or reflect those of the United States Government or any agency thereof.

\section{PACIFIC NORTHWEST LABORATORY operated by}

BATTELLE MEMORIAL INSTITUTE for the

UNITED STATES DEPARTMENT OF ENERGY under Contract DE-AC06-76RLO 1830 


\section{DISCLAMMER}

\section{Portions of this document may be illegible}

in electronic image products. Images are produced from the best available original document. 
DURABILITY OF DOUBLE-SHELL SLURRY FEED GROUTS: FY-90 RESULTS

R. O. Lokken

P. F. C. Martin

December 1992

Prepared for

the U.S. Department of Energy under Contract DE-ACO6-76RLO 1830

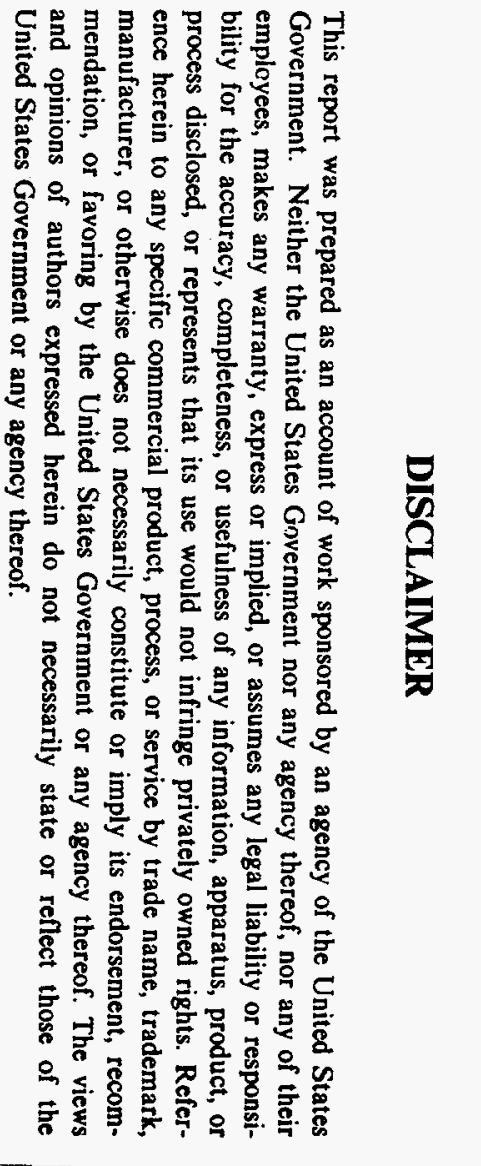

Pacific Northwest Laboratory
Richland Washington 


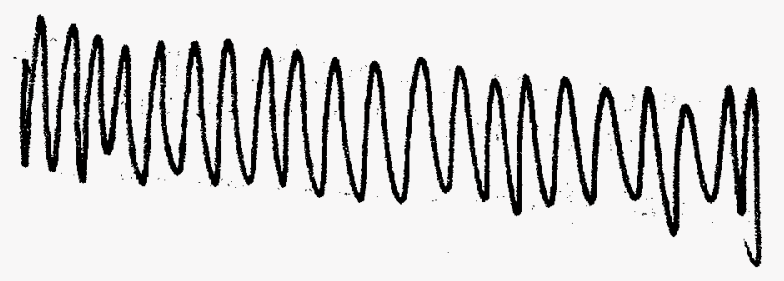




\section{SUMMARY}

This report summarizes results from studies conducted during FY 1990 to assess the durability of grouted double-shell slurry feed (DSSF) waste. These studies were performed in support of Westinghouse Hanford Company's Grout Disposal Program to determine the physical and chemical properties of simulated DSSF grouts cured at elevated temperatures.

Previous studies (Lokken et al. 1989 and Lokken et al. 1992a) have indicated a strong impact from curing temperature and curing time on the strength and leach resistance of DSSF grouts. The current studies were expanded to determine whether these impacts could be attributed to other factors. such as the dry blend composition and the waste concentration. Some major conclusions from these studies include the following:

- Grouts prepared with dry blends containing $40 \mathrm{wt} \% 1$ imestone had lower strengths than grouts prepared without limestone.

- Compressive strengths decreased with increased curing temperature.

- Leach resistance decreased with increased curing temperature and curing time, with curing time having the greatest effect at the lower temperature.

- Waste concentration (dilution) had a major, positive effect on leachability, i.e., leach resistance increased for the grouts prepared with dilute DSSF.

- Nitrate leach resistance increased with high slag-to-cement ratios, dilute DSSF and low curing temperatures.

- The amount of drainable liquids for the grouts prepared with diluted DSSF was lowest when the slag content was high, suggesting that the slag reacts faster than the fly ash to produce a rigid structure within the grout that minimizes particle settling.

- The two most significant factors affecting the grout properties were the slag-to-cement ratio and waste dilution. Interactions between these two factors were also significant, indicating that reactions between the slag and the waste appear to dominate the properties of DSSF grouts.

- The effects of curing time and curing temperature were consistent with results from previous studies (Lokken et a1. 1989). 


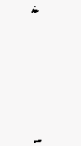




\section{CONTENTS}

SUMMARY

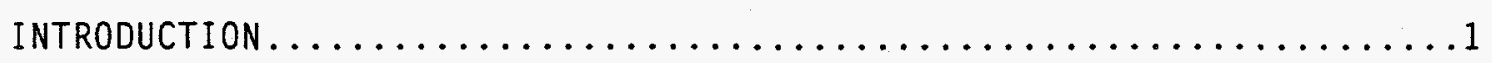

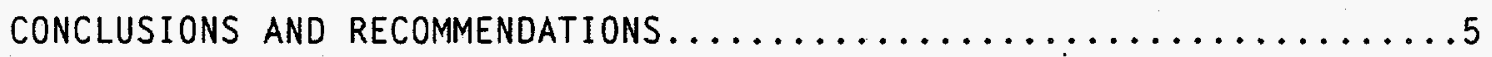

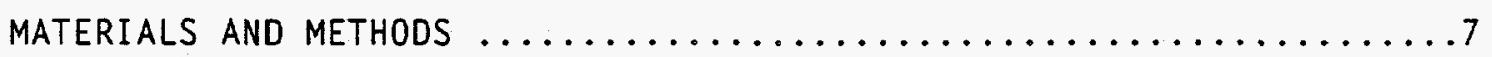

SIMULATED WASTE AND DRY BLEND...................

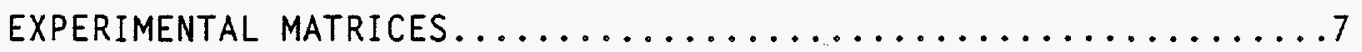

GROUT PREPARATION ...........................

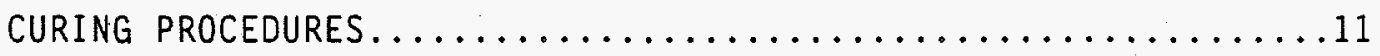

PHYSICAL PROPERTY TESTS..........................

PORE SIZE DISTRIBUTION............................

AMERICAN NUCLEAR SOCIETY (ANS 16.1 ) LEACH TEST ............ 12

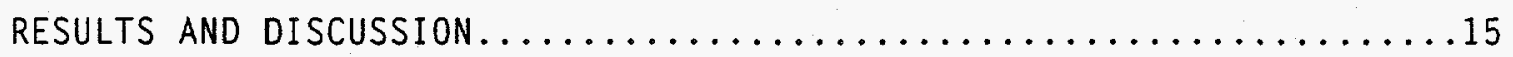

SLURRY PROPERTIES ............................

COMPRESSIVE STRENGTH, DENSITY, AND MOISTURE CONTENT......... IT

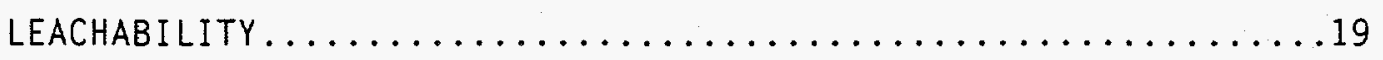

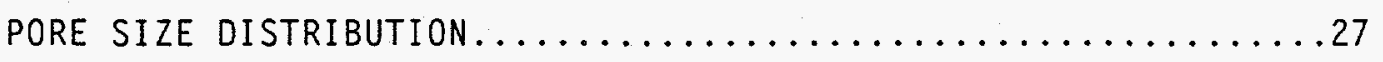

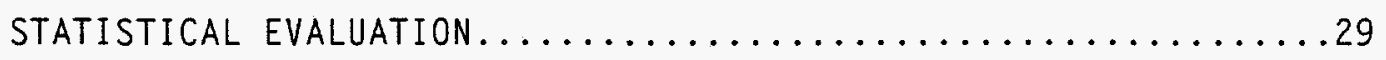

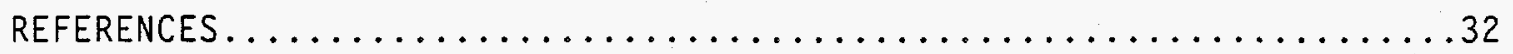

APPENDIX - SUMMARIES OF THE MULTIPLE REGRESSION ANALYSES .........A1 


\section{TABLES}

1. Composition of Simulated DSSF $\ldots \ldots \ldots \ldots \ldots \ldots \ldots \ldots \ldots \ldots$

2. Oxide Composition of Blast Furnace Slag, Class F Fly Ash.

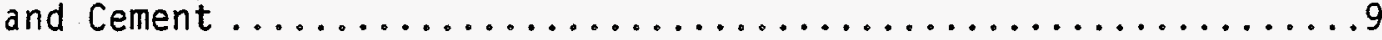

3. Concentration of Trace Metals in Ground Blast Furnace

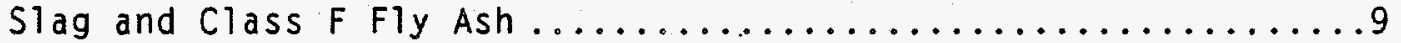

4. Experimental Matrix for Determining the Effects of Dry Blend Composition, Waste Composition, and Curing Temperature on

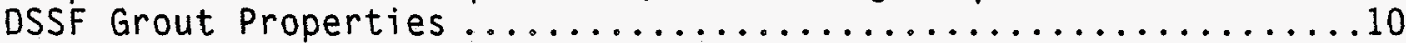

5. Experimental Matrix for Determining the Effect of Curing Conditions and Dry Blend Composition on Grout Properties .......11

6. Critical Flow Rate, Density, and Drainable Liquid Data for

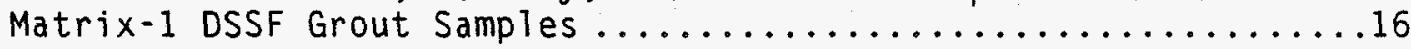

7. Critical Flow Rate and Density Data for Matrix-2 DSSF Grout

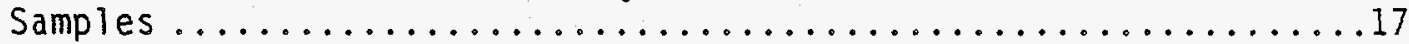

8. Bulk Density, Compressive Strength, and Evaporable Water Content Data for Matrix-1 DSSF Grout Samples ................. 18

9. Bulk Density, Compressive Strength, and Evaporable Water Content Data for Matrix-2 DSSF Grout Samples .................. 19

10. Average $\mathrm{NO}_{3}$ and $\mathrm{Na}$ Leachability Indices for Matrix-1 DSSF Grout Samples Leached by the ANS 16.1 Procedure .............22

11. Average $\mathrm{NO}_{3}$ and $\mathrm{Na}$ Leachability Indices for Matrix-2 DSSF Grout Samples Leached by the ANS 16.1 Procedure .............23

12. Results from the Statistical Evaluation of Main Effects and Two-Way Interactions for Matrix-1 Data ....................... 
1. Cumulative Fraction of Nitrate Leached from DSSF Grout Samples Prepared with Fu11-Strength DSSF and Cured at $95^{\circ} \mathrm{C} \ldots \ldots \ldots \ldots 24$

2. Cumulative Fraction of Nitrate Leached from DSSF Grout Samples Prepared with Fu11-Strength DSSF and Cured at $55^{\circ} \mathrm{C} \ldots \ldots \ldots \ldots 24$

3. Cumulative Fraction of Nitrate Leached from DSSF Grout Samples

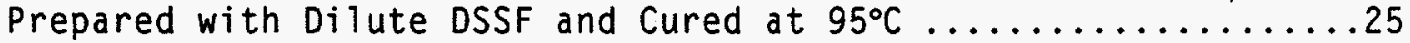

4. Cumulative Fraction of Nitrate Leached from DSSF Grout Samples Prepared with Dilute DSSF and Cured at $55^{\circ} \mathrm{C} \ldots \ldots \ldots \ldots \ldots \ldots . \ldots 25$

5. Cumulative Fraction of Nitrate Leached from Matrix-2 DSSF Grout

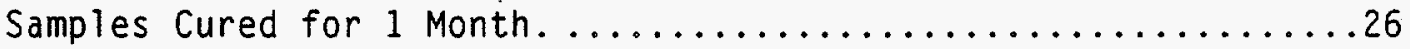

6. Cumulative Fraction of Nitrate Leached from Matrix-2 DSSF Grout

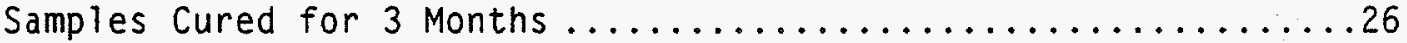

7. Pore Size Distribution of DSSF Grout Samples Prepared with

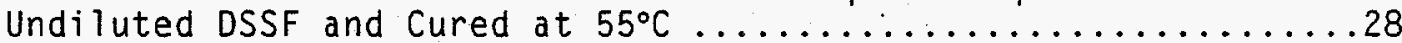

8. Pore Size Distribution of DSSF Grout Samples Prepared with

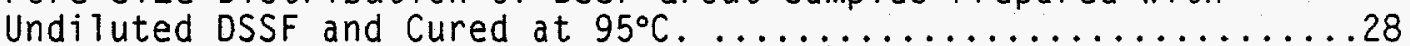

9. Pore Size Distribution of DSSF Grout Samples Prepared with 3.6 wt\% Cement, 28.2 wt\% Fly Ash, 28.2 wt\% Siag, and 40 wt\% Limestone Flour. 


\section{INTRODUCTION}

Current plans for disposal of the low-level fraction of selected doubleshell tank wastes at Hanford, Washington include grouting. Grout disposal in this application is the process of mixing low-level liquid waste with cementitious powders and pumping the resultant slurry to near-surface, underground concrete vaults. Once the slurry is in the vaults, the hydration reactions that occur result in the formation of a solid product that binds and/or encapsulates the radioactive and hazardous constituents.

Cementitious materials have been or will be used at many locations for the solidification and disposal of low-level radioactive wastes. Oak Ridge National Laboratory (ORNL) began disposing of low-level liquid wastes in 1966 using a process known as hydraulic fracturing (de Laguna 1966. Weeren 1976). This process involved mixing liquid wastes with a blend of cement, fly ash, pottery clay, and attapulgite clay, and pumping the slurry at 3000 to 5000 psi into shale formations underlying the ORNL site. The high pressures caused the shale to fracture, and the grout filled the resultant fissures. The Savannah River Plant (SRP) is planning to dispose of 400 million liters of a low-level salt solution using the "saltstone" process (Langton 1988 , Wilhite et al.

1988). Saltstone is the name given to the product prepared by mixing the salt solution with a blend of fly ash, blast furnace slag, and cement. This process is very similar to the grouting process at Hanford (Guymon et al. 1988). Both processes use the same type of dry solids, and the major constituents in the waste solutions are the same (i.e., $\mathrm{NaNO}_{3}, \mathrm{NaNO}_{2}, \mathrm{NaAl}(\mathrm{OH})_{4}$ and $\mathrm{NaOH}$ ).

Westinghouse Hanford Company (WHC) operates the Grout Treatment Facility (GTF) for the U.S. Department of Energy (DOE). The GTF includes the Dry Materials Facility (DMF), the Grout Processing Facility (GPF), and the grout disposal vaults. The DMF receives, stores, batches, and blends the individual dry materials for use in the grouting operation. The blended solids are transported to the site of the GPF where they are mixed with the low-level waste in a continuous process at rates up to 70 gallons of grout per minute. The grout slurry is pumped to underground concrete vaults where it hardens and immobilizes the hazardous and radioactive constituents through chemical reactions and/or microencapsulation. 
Pacific Northwest Laboratory(a) (PNL) provides support to the Grout Disposal Program at Hanford through laboratory support activities (Lokken et al. 1987), radioactive grout leach testing (Serne et al. 1987), performance assessments (Sewart et a 1. 1987), and pilot-scale tests (Fow et al. 1987). A major pilot-scale test was performed in 1986 with a simulated phosphate/sulfate waste (PSW) to assess the effectiveness of the grouting operations and to characterize the grout produced with pilot-scale equipment and cured in a large mass. The results of that test are presented in Fow et al. (1987), Lokken et a1. (1988), and Lokken and Mitchell (1988).

Characterization of grout samples taken from an actual disposal vault have also been reported by Martin and Lokken (1992).

Grout disposal will be used for double-shell slurry feed (DSSF) waste, one of the types of low-level wastes stored in double-shell tanks on the Hanford site. The initial formulation for DSSF waste included a dry blend consisting. of approximately 47 wt\% ground blast furnace slag. 47 wt\% fly ash, and 6 wt\% Portland cement. The dry blend is mixed with liquid waste at a nominal ratio of $9 \mathrm{lb}$ of solids per gallon of waste $(1080 \mathrm{~g} / \mathrm{L})$. This formulation was developed to meet specified criteria for processing, leachability, and physical properties of the grouted waste form. Because of time constraints during formulation studies, tests using these grouts were conducted after relatively short curing times at temperatures that do not accurately simulate the temperatures that will occur under the expected disposal conditions. While the grouts prepared with the initial formulation met most formulation criteria. additional information was needed to verify that long-term reactions within the grout at elevated temperatures will not sacrifice the integrity of the disposal system and result in less favorable performance.

A second pilot-scale test using the formulation described above was conducted at PNL in 1988. The results of this test and of subsequent product characterization are presented by Lokken et al. (1992b). Results of the pilot-scale test indicated that the temperature rise during curing of DSSF grout produced with the initial dry blend formulation would exceed design criteria. Also, long-term, high-temperature curing studies on this

(a) Pacific Northwest Laboratory is operated by Battelle Memorial Institute for the U. S. Department of Energy under contract DE-AC06-76RLO 1830. 
formulation showed that leach resistance and compressive strengths decreased with increases in temperature and curing time (Lokken et al. 1989 and Lokken et al. 1992a). Subsequently, a modified formulation was tested to reduce the total heat generated during hydration. This formulation included $40 \mathrm{wt} \%$ ground limestone which was added to reduce the amount of heat-generating solids. The remainder of the formulation included 4 wt\% portland cement, 28 wt\% fly ash, and 28 wt\% blast furnace slag.

The objective of this study was to qualitatively determine which factors affect selected properties of DSSF grouts. The factors included dry blend composition, waste composition (by dilution), curing temperature, curing time, and the presence (or absence) of additional water during curing. Properties that were measured included critical flow rate, slurry density, bulk density, drainable liquids, compressive strength, evaporable water, and leach resistance. 


\section{CONCLUSIONS AND RECOMMENDATIONS}

Two statistically designed experimental matrices were used to determine the effects of various factors on the properties of DSSF grouts. One matrix utilized a Plackett-Burman screening design to determine the effects of fly ash-to-cement ratio, slag-to-cement ratio, limestone content, curing temperature, curing time, and the effect of additional water available during hydration. The only significant effect indicated by the data from this matrix was the fly ash-to-cement ratio. This ratio had significant effects on the critical flow rate, bulk density, evaporable water content, and on the nitrate and sodium leachability. The effects of all the other factors on the selected grout properties were not significant at the $95 \%$ confidence levels. Because the experimental matrix was designed for screening studies, only the main effects of the variables could be determined; interactions between variables were not assessed. However, the data from this matrix indicate the following:

- Leach resistance decreases with increased curing temperature and curing time, with curing time having the greatest effect at the lower temperature.

- Grouts prepared with dry blends containing 40 wt\% 1 imestone had lower strengths than grouts prepared without 1 imestone.

- Compressive strengths decreased with increased curing temperature.

- The presence of additional water during curing had no significant effects on the grout properties; however, the amount of water adsorbed by the grouts was less than 1 wt\%.

The other matrix was based on a two-level, fourth-order factorial design, with three replicates at the center of the design space. This design allows for the determination of main effects of the variables and two-way interactions between variables. Based on the statistical analyses of these data, the following conclusions can be made:

- Waste concentration (dilution) had a major, positive effect on leachability, i.e., leach resistance increased for the grouts prepared with dilute DSSF. Grouts prepared with dilute DSSF had drainable liquids up to about 30 vol\%. 
- Nitrate leach resistance increased with high slag-to-cement ratios, dilute DSSF and low curing temperatures.

- A combination of high slag content, no fly ash, undiluted DSSF, and high temperature resulted in the worst leachability for nitrate.

- The amount of drainable liquids for the grouts prepared with diluted DSSF was lowest when the slag content was high, suggesting that the slag reacts faster than the fly ash to produce a rigid structure within the grout that minimizes particle settling.

- The two most significant factors affecting the grout properties were the slag-to-cement ratio and waste dilution. Interactions between these two factors were also significant, indicating that reactions between the slag and the waste appear to dominate the properties of DSSF grouts.

The effects of curing time and curing temperature were consistent with results from previous studies (Lokken et a1. 1989 and Lokken et a1. 1992a).

Pore size distribution measurements were conducted to determine whether leach resistance could be correlated with the pore size distribution. However, the high salt content in pore solutions apparently left precipitated salt crystals in the pores, which in turn did not allow an accurate representation of the pores available for ionic diffusion during leaching.

The results obtained from these studies will provide valuable guidance in defining future formulation enhancement activities aimed at improving grout properties. 


\section{MATERIALS AND METHODS}

\section{SIMULATED WASTE AND DRY BLEND}

The simulated DSSF waste used in these studies was obtained from a large batch prepared for use in the November 1988 pilot-scale test of grout processing characteristics (Lokken 1992b). The nominal and analyzed composition of the simulated waste is listed in Table 1.

Dry blends were prepared with a combination of blast furnace slag, type I/II Portland cement and limestone flour obtained from Ash Grove Cement West, and class $F$ fly ash from Centralia. Washington. The dry materials were mixed in a V-blender for 23 hours prior to grout preparation. The oxide composition of the major constituents in the slag. fly ash, and cement, as determined by inductively coupled plasma (ICP) spectroscopy, is listed in Table 2. Table 3 lists the concentrations of trace metals in these materials as determined by $X$-ray fluorescence (XRF) analysis.

\section{EXPERIMENTAL MATRICES}

Two experimental matrices were used in the studies. The first matrix, listed in Table 4, was used to determine the effects of various factors on the properties of cured DSSF grouts. The specific factors included dry blend composition, waste composition, and curing temperature. This matrix utilizes a two-level fourth-order factorial design with three replicates of the midpoint of the design.

The second experimental matrix. listed in Table 5, was used to determine the effects of various curing conditions and dry blend compositions on DSSF grout properties. This matrix follows a Plackett-Burman screening design and was used to determine main effects of the various factors.

\section{GROUT PREPARATION}

Grouts were prepared using a Hobart mixer and a wire whip. The waste was preheated to approximately $45^{\circ} \mathrm{C}$, and then poured into the mixer bow 1 . Room temperature dry blend was added to the waste at a mix ratio of $9 \mathrm{lb} / \mathrm{gal}$ 
TABLE 1. Composition of Simulated DSSF Waste

\begin{tabular}{|c|c|c|}
\hline \multirow[b]{2}{*}{ Species } & \multicolumn{2}{|c|}{ Composition, $\mathrm{g} / \mathrm{L}$} \\
\hline & Analyzed (a) & Nominal $(b)$ \\
\hline Al & 22.4 & 20.3 \\
\hline B & 0.136 & 0.105 \\
\hline $\mathrm{Ba}$ & 0.6 & 0.623 \\
\hline $\mathrm{Ca}$ & 0.573 & 0.2 \\
\hline $\mathrm{Cr}$ & 1.26 & 1.15 \\
\hline $\mathrm{Fe}$ & 1.49 & 1.41 \\
\hline$k$ & 11.5 & 9.72 \\
\hline $\mathrm{Mg}$ & 0.32 & \\
\hline Mn & 3.01 & 2.75 \\
\hline Mo & 0.068 & 0.049 \\
\hline $\mathrm{Na}$ & 122 & 121.8 \\
\hline Si & 0.502 & 0.56 \\
\hline $\mathrm{Zn}$ & 2.93 & 1.63 \\
\hline $\mathrm{Cl}^{-}$ & 5.36 & 3.86 \\
\hline $\mathrm{NO}_{2}^{-}$ & 27.2 & 23.0 \\
\hline $\mathrm{PO}_{4}^{-3}$ & 5.4 & 5.65 \\
\hline $\mathrm{NO}_{3}^{-}$ & 186 & 154.4 \\
\hline $\mathrm{SO}_{4}^{-2}$ & 5.1 & 5.05 \\
\hline $\operatorname{TOC}(\mathrm{c})$ & 1.556 & 1.28 \\
\hline
\end{tabular}

(a) Analyzed for this study

(b) Claghorn (1987)

(c) Total organic carbon as EDTA and citrate

$(1.08 \mathrm{~kg} / \mathrm{L})$. After mixing, grout slurry samples were tested for density and for rheology using a Fann viscometer. The grouts were prepared in random order as 1 isted by run number in Tables 4 and 5 . The slurry was prepared for curing as discussed below. 
TABLE 2. Oxide Composition of Blast Furnace Slag, Class F Fly Ash, and Cement

\begin{tabular}{|c|c|c|c|}
\hline \multirow[b]{2}{*}{ Oxide } & \multicolumn{3}{|c|}{ Composition, wtq(a) } \\
\hline & Slag & Fly Ash & Cement \\
\hline $\mathrm{A}_{2} 2 \mathrm{O}_{3}$ & 13.4 & 23.5 & 3.3 \\
\hline $\mathrm{B}_{2} \mathrm{O}_{3}$ & & 0.5 & 0.105 \\
\hline $\mathrm{BaO}$ & 0.117 & 0.169 & 0.084 \\
\hline $\mathrm{CaO}$ & 43.4 & 8.05 & 65.4 \\
\hline $\mathrm{Fe}_{2} \mathrm{O}_{3}$ & 0.377 & 5.73 & 4.08 \\
\hline $\mathrm{K}_{2} \mathrm{O}$ & 0.89 & 0.98 & 0.65 \\
\hline $\mathrm{MgO}$ & 5.62 & 1.57 & 1.38 \\
\hline $\mathrm{MnO}_{2}$ & 1.03 & 0.088 & 0.072 \\
\hline $\mathrm{Na}_{2} \mathrm{O}$ & 0.401 & 3.02 & 0.32 \\
\hline $\mathrm{P}_{2} \mathrm{O}_{5}$ & & 0.94 & \\
\hline $\mathrm{SiO}_{2}$ & 33.3 & 47.8 & 22.2 \\
\hline Sro & 0.078 & 0.31 & 0.035 \\
\hline $\mathrm{TiO}_{2}$ & 1.08 & 4.43 & 0.22 \\
\hline Total & 99.693 & 97.087 & 97.846 \\
\hline
\end{tabular}

IABLE 3. Concentration of Trace Metals in Ground Blast Furnace Slag and Class F Fly Ash

\begin{tabular}{|c|c|c|}
\hline \multirow{2}{*}{$\begin{array}{l}\text { Trace } \\
\text { Meta } \\
\end{array}$} & \multicolumn{2}{|c|}{ Concentration, $\mathrm{ppm}$ (a } \\
\hline & S1ag & Fly Ash \\
\hline $\begin{array}{l}\mathrm{Ag} \\
\mathrm{As} \\
\mathrm{Cd} \\
\mathrm{Hg} \\
\mathrm{Pb} \\
\mathrm{Se}\end{array}$ & $\begin{array}{c}<4.6 \\
3.1 \\
<5.2 \\
<4.3 \\
<3.9 \\
2.0\end{array}$ & $\begin{array}{c}<4.7 \\
22.2 \\
<5.1 \\
<4.6 \\
22.9 \\
2.0\end{array}$ \\
\hline
\end{tabular}

(a) Determined by XRF analysis 
IABLE 4. Experimental Matrix for Determining the Effects of Dry Blend Composition, Waste Composition, and Curing Temperature on DSSF Grout Properties (A11 grouts were cured for 1 month)

\begin{tabular}{|c|c|c|c|c|c|c|c|c|c|}
\hline \multirow{2}{*}{$\begin{array}{l}\text { Run } \\
\text { No. }\end{array}$} & \multirow{2}{*}{$\begin{array}{c}\text { Trial } \\
\text { No. }\end{array}$} & \multirow[b]{2}{*}{$F / C^{(b)}$} & \multirow[b]{2}{*}{$S / C^{(c)}$} & \multirow{2}{*}{$\begin{array}{l}\text { Waste } \\
\text { Dil. }\end{array}$} & \multirow{2}{*}{ Temp. } & \multicolumn{4}{|c|}{ Dry Blend Composition(a) } \\
\hline & & & & & & $C$ & $F$ & $S$ & $\mathrm{~L}$ \\
\hline 15 & 1 & 0 & 0 & $1 X$ & 55 & 60.0 & 0 & 0 & 40.0 \\
\hline 8 & 2 & 8 & 0 & $1 X$ & 55 & 6.7 & 53.3 & 0 & 40.0 \\
\hline 7 & 3 & 0 & 8 & $1 X$ & 55 & 6.7 & 0 & 53.3 & 40.0 \\
\hline 4 & 4 & 8 & 8 & $1 X$ & 55 & 3.5 & 28.2 & 28.2 & 40.0 \\
\hline 6 & 5 & 0 & 0 & $100 x$ & 55 & 60.0 & 0 & 0 & 40.0 \\
\hline 3 & 6 & 8 & 0 & $100 x$ & 55 & 6.7 & 53.3 & 0 & 40.0 \\
\hline 2 & 7 & 0 & 8 & $100 x$ & 55 & 6.7 & 0 & 53.3 & 40.0 \\
\hline 10 & 8 & 8 & 8 & $100 x$ & 55 & 3.5 & 28.2 & 28.2 & 40.0 \\
\hline 18 & 9 & 0 & 0 & $1 X$ & 95 & 60.0 & 0 & 0 & 40.0 \\
\hline 19 & 10 & 8 & 0 & $1 X$ & 95 & 6.7 & 53.3 & 0 & 40.0 \\
\hline 14 & 11 & 0 & 8 & $1 X$ & 95 & 6.7 & 0 & 53.3 & 40.0 \\
\hline 12 & 12 & 8 & 8 & $1 X$ & 95 & 3.5 & 28.2 & 28.2 & 40.0 \\
\hline 11 & 13 & 0 & 0 & $100 x$ & 95 & 60.0 & 0 & 0 & 40.0 \\
\hline 16 & 14 & 8 & 0 & $100 x$ & 95 & 6.7 & 53.3 & 0 & 40.0 \\
\hline 17 & 15 & 0 & 8 & $100 x$ & 95 & 6.7 & 0 & 53.3 & 40.0 \\
\hline 13 & 16 & 8 & 8 & $100 x$ & 95 & 3.5 & 28.2 & 28.2 & 40.0 \\
\hline 1 & 17 & 4 & 4 & $10 x$ & 75 & 6.7 & 26.7 & 26.7 & 40.0 \\
\hline 5 & 18 & 4 & 4 & $10 x$ & 75 & 6.7 & 26.7 & 26.7 & 40.0 \\
\hline 9 & 19 & 4 & 4 & $10 x$ & 75 & 6.7 & 26.7 & 26.7 & 40.0 \\
\hline
\end{tabular}

(a) $C=$ type I/II Portiand cement $F=$ Class F fly ash

$\mathrm{S}=$ Ground blast furnace slag

(b) Fly ash-to-cement ratio

(c) Slag-to-cement ratio 
IABLE 5. Experimental Matrix for Determining the Effect of Curing Conditions and Ory Blend Composition on Grout Properties

\begin{tabular}{|c|c|c|c|c|c|c|c|c|c|c|}
\hline \multirow{2}{*}{$\begin{array}{l}\text { Run } \\
\text { No. }\end{array}$} & \multirow{2}{*}{$\begin{array}{l}\text { Trial } \\
\text { No. }\end{array}$} & \multirow{2}{*}{$F / C^{(b}$} & \multirow[b]{2}{*}{$S / C(c)$} & \multicolumn{3}{|c|}{ Dry Blend Composition } & \multirow{2}{*}{$\frac{w t \%(a)}{S}$} & \multicolumn{3}{|c|}{ Curing Conditions } \\
\hline & & & & $L$ & $C$ & $F$ & & Water (d) & ${ }^{\circ} \mathrm{C}$ & months \\
\hline 10 & 1 & 8 & 8 & 40 & 3.6 & 28.2 & 28.2 & 0 & 95 & 3 \\
\hline 2 & 2 & 8 & 0 & 0 & 11.1 & 88.9 & 0 & 10 & 95 & 3 \\
\hline 8 & 3 & 0 & 8 & 0 & 11.1 & 0 & 88.9 & 10 & 95 & 1 \\
\hline 12 & 4 & 8 & 8 & 0 & 5.8 & 47.1 & 47.1 & 10 & 55 & 1 \\
\hline 4 & 5 & 8 & 8 & 40 & 3.6 & 28.2 & 28.2 & 0 & 55 & 1 \\
\hline 11 & 6 & 8 & 0 & 0 & 11.1 & 88.9 & 0 & 0 & 55 & 3 \\
\hline 7 & 7 & 0 & 0 & 40 & 60 & 0 & 0 & 0 & 95 & 1 \\
\hline 5 & 8 & 0 & 0 & 0 & 100 & 0 & 0 & 10 & 55 & 3 \\
\hline 6 & 9 & 0 & 8 & 40 & 6.7 & 0 & 53.3 & 0 & 95 & 3 \\
\hline 9 & 10 & 8 & 0 & 40 & 6.7 & 53.3 & 0 & 10 & 95 & 1 \\
\hline 1 & 11 & 0 & 8 & 40 & 6.7 & 0 & 53.3 & 10 & 55 & 3 \\
\hline 3 & 12 & 0 & 0 & 0 & 100 & 0 & 0 & 0 & 55 & 1 \\
\hline
\end{tabular}

(a) $\begin{aligned} C & =\text { type I/II Portland cement } \\ F & =\text { Class F fly ash } \\ S & =\text { Ground blast furnace slag } \\ L & =\text { Limestone flour }\end{aligned}$

(b) Fly Ash/Cement ratio

(C) $S i a g / C e m e n t$ ratio

(d) 0 indicates no additional water present during curing 10 indicates that additional water equal to $10 \mathrm{wt} \%$ of the grout was added to the curing container during curing

\section{CURING PROCEDURES}

After mixing, grout slurry was poured into $250-\mathrm{mL}$ plastic graduated cylinders. The cylinders were weighed and then placed into copper tubes. Copper end caps were placed onto the copper tube and the assembly was placed into a steel frame that was used to keep the caps tight. The assemblies were then placed in ovens initially operating at approximately $35^{\circ} \mathrm{C}$. The temperature of the ovens was increased over a 3 -day period to $55^{\circ} \mathrm{C}, 75^{\circ} \mathrm{C}$, or $95^{\circ} \mathrm{C}$.

After curing for the desired time periods, the samples were allowed to cool slowly to room temperature. The grout samples were removed from the graduated cylinders by cutting through the cylinder and then pushing the grout sample out. The grout specimens were weighed and placed into plastic bags until tested. Testing was normally conducted within 5 days after removal. 


\section{PHYSICAL PROPERTY TESTS}

Compressive strength testing was conducted with an Instron(a) test machine at a constant crosshead speed of $0.05 \mathrm{in./min}$. The load-to-failure was determined from the maximum point of a load-deformation curve. Compressive strength values were calculated by dividing the maximum load by the cross sectional surface area of the cylinders. The length-to-diameter ratio of these samples was one. Bulk density was determined by dividing the weight of the compressive strength samples by their bulk volume as determined by length and diameter measurements.

The moisture content, or amount of evaporable water, of the grouts was determined by drying the compressive strength samples (after testing) to a constant weight at $105^{\circ} \mathrm{C} \pm 2^{\circ} \mathrm{C}$.

\section{PORE SIZE DISTRIBUTION}

Pore size distribution was determined for selected samples using mercury intrusion porosimetry. These tests were conducted by Coors Analytical Laboratory. Golden, Colorado. Grout samples were dried to a constant weight at $105^{\circ} \mathrm{C} \pm 2^{\circ} \mathrm{C}$ prior to testing. Testing was conducted at nominal intrusion pressures of 0.5 psia to 60,000 psia, corresponding to pore diameters from $375 \mu \mathrm{m}$ to $0.003 \mu \mathrm{m}$.

\section{AMERICAN NUCLEAR SOCIETY (ANS 16.1) LEACH TEST}

The ANS 16.1 leach test (ANS 1986) was used to determine the effects of curing temperature and curing time on leachability. The test is an intermittent leachate exchange test designed to simulate a dynamic leaching situation. Cylindrical samples were suspended by nylon monofilament in deionized water within polyethylene containers. The leachant volume-to-sample surface area ratio used was $10 \mathrm{~cm}$. The ANS leach tests were conducted for 28 to 35 days. After the elapsed time periods, the samples were removed from the

(a) Instron Corporation. Canton. Massachusetts 
leachates and placed into containers containing fresh leachant. The $\mathrm{pH}$ of the leachates was measured immediately after removing the samples. Aliquots of leachate were filtered through a $0.45 \mu \mathrm{m}$ filter and then submitted for cation analysis by ICP and for anion analysis by ion chromatography (IC).

The ANS 16.1 leach test was used in these studies to determine the relative leaching resistance for major cations and anions and to determine changes in leachability due to different curing conditions. Also, changes in the leaching behavior can provide some insight into physical and chemical changes that may be occurring in the grout. The ANS 16.1 leach test is designed to determine a "figure of merit" parameter called the leachability index (L). The leachability index for a given species is defined as the negative logarithm (base 10) of the effective diffusion coefficient (D) of that species. When less than $20 \%$ of a given species is leached, the effective diffusivity is given by (ANS 1986):

$$
D=\pi\left[\frac{\left(a_{n} / A_{0}\right)}{(\Delta t)_{n}}\right]^{2}\left[\frac{v}{S}\right]^{2} T
$$

where $D$ = effective diffusivity, $\mathrm{cm}^{2} / \mathrm{s}$

$$
\begin{aligned}
a_{n}= & \text { concentration of ion released from the specimen during the } \\
& \text { leaching interval } n \\
A_{0}= & \text { total amount of species in the specimen at the beginning of } \\
& \text { the leach test } \\
(\Delta t)_{n}= & t_{n}-t_{n-1} \text {, duration of the } n \text {-th leaching interval, s } \\
v= & \text { volume of specimen, } \mathrm{cm}^{3} \\
S= & \text { geometric surface area of specimen, } \mathrm{cm}^{2} \\
T= & {\left[1 / 2\left(\sqrt{t_{n}}+\sqrt{t_{n-1}}\right)\right]^{2} \text {, representing the "mean time" of the } } \\
& \text { leaching interval. s. }
\end{aligned}
$$

When greater than $20 \%$ of the total inventory of a species is leached, the effective diffusivity is calculated by:

$$
D=\frac{G d^{2}}{t}
$$

where $D=$ effective diffusivity, $\mathrm{cm}^{2} / \mathrm{s}$

$G=$ dimensionless time factor for cylinder

$d=$ cylinder diameter. $\mathrm{cm}$

$t=$ elapsed leaching time from beginning of test, $s$. 


\section{RESULTS AND DISCUSSION}

This section presents the results of tests conducted to determine the effects of varying conditions and compositions on properties of DSSF grouts.

\section{SLURRY PROPERTIES}

Slurry density and viscometry measurements were conducted on all grout slurry samples to calculate the critical flow rate, i.e., the minimum flow rate required to attain turbulent flow in a nominal 2 -in.-dia. pipe. The results of the density measurements and critical flow rate calculations are shown in Table 6 for the matrix-1 samples and in Table 7 for the matrix-2 samples. The data in Table 6 clearly show the dependence of waste dilution on the grout slurry densities, with the grouts prepared with diluted DSSF having the lowest densities. The critical flow rates also follow similar trends, with undiluted DSSF resulting in grouts with the highest values. The dry blend parameter having the greatest effect on both density and critical flow rate was the fly ash/cement ratio, i.e.. high fly ash contents resulted in lower densities and lower critical flow rates. This is evidenced in both Table 6 and Table 7 .

The amount of 28-day drainable liquids is also very much dependent on the waste dilution, as seen in Table 6 . All grouts prepared with undiluted DSSF had no drainable liquids. The grouts prepared with waste diluted 100 times had drainable liquid contents up to about 31 vol\%. The amount of drainable liquids for the grouts prepared with diluted DSSF was lowest when the slag content was high. suggesting that the slag reacts faster than the fly ash to. produce a rigid structure within the grout that minimizes particle settling. only two matrix-2 samples contained small amounts (less than 1 vol\%) of drainable liquids.

Additional discussions of slurry density, critical flow rate, and drainable liquid data are presented in the "Statistical Evaluation" section. 
IABLE 6. Critical Flow Rate, Density, and Drainable Liquid Data for Matrix-1 DSSF Grout Samples (All samples were cured for 1 month)

\begin{tabular}{|c|c|c|c|c|c|c|c|c|}
\hline $\begin{array}{l}\text { Run } \\
\text { No. }\end{array}$ & $\begin{array}{c}\text { Trial } \\
\text { No. } \\
\end{array}$ & $\mathrm{F} / \mathrm{C}$ & $S / C$ & Dil. & $\begin{array}{l}\text { Temp. } \\
{ }^{\circ} \mathrm{C} \\
\end{array}$ & $\begin{array}{r}\text { Slurry } \\
\text { Density. } \\
\text { Ib/gal } \\
\end{array}$ & $\begin{array}{c}\text { Critical } \\
\text { Flow } \\
\text { Rate, } \\
\text { gpm } \\
\end{array}$ & $\begin{array}{c}\text { Drainable } \\
\text { Liquids. } \\
\text { Vol\% } \\
\end{array}$ \\
\hline 15 & 1 & 0 & 0 & $1 X$ & 55 & 14.37 & 29.94 & 0.0 \\
\hline 8 & 2 & 8 & 0 & $1 X$ & 55 & 13.66 & 12.45 & 0.0 \\
\hline 7 & 3 & 0 & 8 & $1 X$ & 55 & 14.14 & 25.37 & 0.0 \\
\hline 4 & 4 & 8 & 8 & $1 X$ & 55 & 13.82 & 15.91 & 0.0 \\
\hline 6 & 5 & 0 & 0 & $100 x$ & 55 & 12.84 & 9.64 & 19.6 \\
\hline 3 & 6 & 8 & 0 & $100 x$ & 55 & 12.19 & 6.27 & 30.9 \\
\hline 2 & 7 & 0 & 8 & $100 x$ & 55 & 12.57 & 18.82 & 4.8 \\
\hline 10 & 8 & 8 & 8 & $100 x$ & 55 & 12.32 & 8.68 & 15.2 \\
\hline 18 & 9 & 0 & 0 & IX & 95 & 14.41 & 32.31 & 0.0 \\
\hline 19 & 10 & 8 & 0 & $1 X$ & 95 & 13.58 & 12.93 & 0.0 \\
\hline 14 & 11 & 0 & 8 & $1 X$ & 95 & 14.12 & 25.04 & 0.0 \\
\hline 12 & 12 & 8 & 8 & $1 X$ & 95 & 13.79 & 17.15 & 0.0 \\
\hline 11 & 13 & 0 & 0 & $100 x$ & 95 & 12.86 & 9.62 & 20.2 \\
\hline 16 & 14 & 8 & 0 & $100 x$ & 95 & 12.23 & 6.25 & 30.2 \\
\hline 17 & 15 & 0 & 8 & $100 x$ & 95 & 12.59 & 19.04 & 3.5 \\
\hline 13 & 16 & 8 & 8 & $100 x$ & 95 & 12.34 & 9.46 & 15.3 \\
\hline 1 & 17 & 4 & 4 & $10 x$ & 75 & 12.48 & 7.24 & 8.4 \\
\hline 5 & 18 & 4 & 4 & $10 x$ & 75 & 12.43 & 8.60 & 7.9 \\
\hline 9 & 19 & 4 & 4 & $10 x$ & 75 & 12.44 & 9.45 & 8.6 \\
\hline
\end{tabular}


TABLE 7. Critical Flow Rate and Density Data for Matrix-2 DSSF Grout Samples(a)

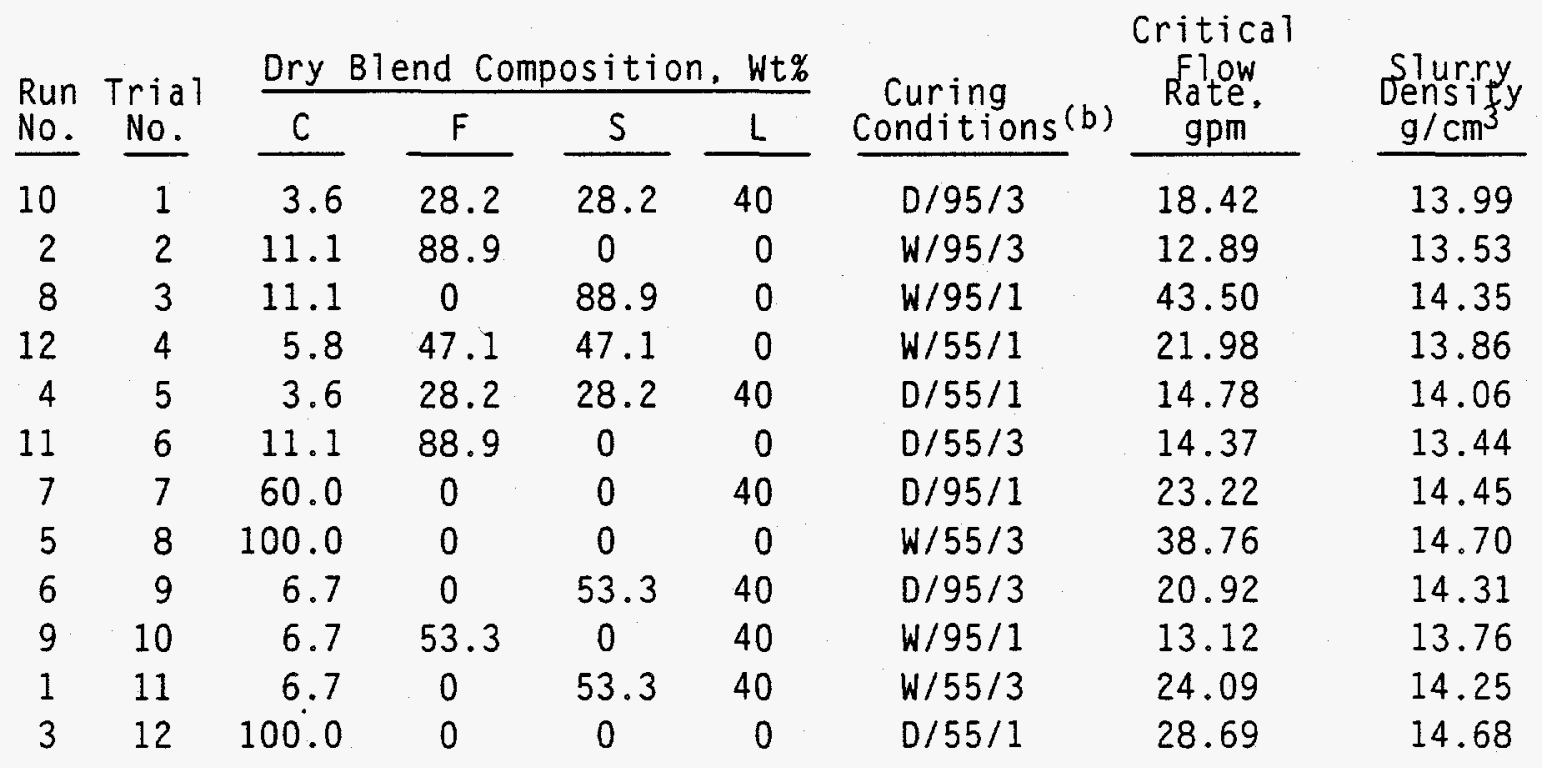

(a) A1l grouts were prepared with undiluted DSSF

(b) $X / Y Y / Z$

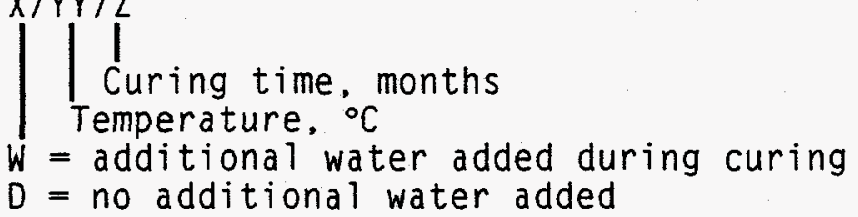

\section{COMPRESSIVE STRENGTH. DENSITY, AND MOISTURE CONTENT}

Unconfined compressive strength, bulk density, and evaporable water content data for the matrix-1 and matrix-2 DSSF grout samples are given in Tables 8 and 9, respectively. There does not appear to be a large effect from any of the parameters on the density of the Matrix-1 samples. Although dilution had a large effect on the slurry density, dilution also played a significant role in the amount of drainable liquids. The net effect was densification of the grout due to particle settling prior to grout setting. The data in Table 9 show a relationship for bulk density with dry blend composition. In general, the density increases with decreases in fly ash content and increases in cement and slag content. Limestone content and curing conditions do not have an effect on the density. 
Compressive strength values shown in Table 8 indicate an effect from temperature on strength. Increased temperature results in higher strengths for those grouts with fly ash and without slag $(F / C=8$ and $S / C=0)$, and lower strengths for the others. Dilution also has an effect on the strengths, particularly for the blends without fly ash and slag. For example, comparing trial numbers 1 and 5, dilution of the DSSF resulted in a grout strength of 1022 psi compared with only 370 psi for the grout prepared with undiluted DSSF. The compressive strengths of the matrix-2 samples are influenced by the presence of 1 imestone in the grouts, with lower strengths for those samples containing limestone.

Additional discussions of compressive strength, density, and evaporable water data are presented in the "Statistical Evaluation" section.

TABLE 8. Bulk Density, Compressive Strength, and Evaporable Water Content Data for Matrix-1 DSSF Grout Samples (A11 samples were cured for 1 month)

\begin{tabular}{|c|c|c|c|c|c|c|c|}
\hline $\begin{array}{l}\text { Run Trial } \\
\text { No. No. } \\
\end{array}$ & $\mathrm{F} / \mathrm{C}$ & $s / C$ & DiT. & $\begin{array}{l}\text { Temp } \\
{ }^{\circ} \mathrm{C} \\
\end{array}$ & $\begin{array}{l}\text { Density. } \\
\mathrm{g} / \mathrm{cm}^{3} \\
\end{array}$ & $\begin{array}{c}\text { Strength, } \\
\text { psi } \\
\end{array}$ & $\begin{array}{c}\text { Content } \\
w t \%\end{array}$ \\
\hline 15 & 0 & 0 & $1 x$ & 55 & 1.723 & 370 & 24.10 \\
\hline 2 & 8 & 0 & $1 x$ & 55 & 1.664 & 371 & 27.19 \\
\hline 3 & 0 & 8 & $1 X$ & 55 & 1.707 & 973 & 24.22 \\
\hline 4 & 8 & 8 & $1 X$ & 55 & 1.671 & 613 & 26.44 \\
\hline 5 & 0 & 0 & $100 x$ & 55 & 1.713 & 1022 & 23.76 \\
\hline 6 & 8 & 0 & $100 x$ & 55 & 1.699 & 85 & 24.43 \\
\hline 7 & 0 & 8 & $100 x$ & 55 & 1.546 & 504 & 31.98 \\
\hline 10 & 8 & 8 & $100 x$ & 55 & 1.592 & 501 & 30.09 \\
\hline 18 & 0 & 0 & $1 X$ & 95 & 1.735 & 359 & 23.57 \\
\hline 10 & 8 & 0 & $1 x$ & 95 & 1.671 & 254 & 26.75 \\
\hline 11 & 0 & 8 & $1 x$ & 95 & 1.706 & 348 & 24.34 \\
\hline 12 & 8 & 8 & $1 x$ & 95 & 1.680 & 367 & 26.31 \\
\hline 13 & 0 & 0 & $100 x$ & 95 & 1.708 & 613 & 24.63 \\
\hline 14 & 8 & 0 & $100 x$ & 95 & 1.717 & 236 & 24.19 \\
\hline 15 & 0 & 8 & $100 x$ & 95 & 1.536 & 373 & 33.28 \\
\hline 16 & 8 & 8 & $100 x$ & 95 & 1.576 & 358 & 30.64 \\
\hline 17 & 4 & 4 & $10 x$ & 75 & 1.550 & 254 & 31.88 \\
\hline 18 & 4 & 4 & $10 x$ & 75 & 1.558 & 260 & 32.33 \\
\hline 19 & 4 & 4 & $10 x$ & 75 & 1.555 & 269 & 32.03 \\
\hline
\end{tabular}


IABLE 9. Bulk Density, Compressive Strength, and Evaporable Water Content Data for Matrix 2 DSSF Grout Samples

\begin{tabular}{|c|c|c|c|c|c|c|c|c|c|}
\hline $\begin{array}{l}\text { Run } \\
\text { No. }\end{array}$ & $\begin{array}{c}\text { Trial } \\
\text { No. }\end{array}$ & Dry & lend $C$ & positi & $\frac{W}{L}$ & $\begin{array}{l}\text { Curing } \\
\text { Conditions }\end{array}$ & $\begin{array}{l}\text { Compressive } \\
\text { Strength } \\
\text { (a) psi }\end{array}$ & $\begin{array}{l}\text { Bulk } \\
\text { Density } \\
\text { g/cm3 }\end{array}$ & $\begin{array}{c}\text { Evaporable } \\
\text { Water } \\
\text { Content } \\
\text { wt\% }\end{array}$ \\
\hline 10 & 1 & 3.6 & 28.2 & 28.2 & 40 & $0 / 95 / 3$ & 212 & 1.695 & 33.9 \\
\hline 2 & 2 & 11.1 & 88.9 & 0 & 0 & $W / 95 / 3$ & 1512 & 1.629 & 34.5 \\
\hline 8 & 3 & 11.1 & 0 & 88.9 & 0 & $W / 95 / 1$ & 1330 & 1.719 & 29.3 \\
\hline 12 & 4 & 5.8 & 47.1 & 47.1 & 0 & $W / 55 / 1$ & 1292 & 1.649 & 33.6 \\
\hline 4 & 5 & 3.6 & 28.2 & 28.2 & 40 & $D / 55 / 1$ & 899 & 1.679 & 33.5 \\
\hline 11 & 6 & 11.1 & 88.9 & 0 & 0 & $0 / 55 / 3$ & 1449 & 1.619 & 34.2 \\
\hline 7 & 7 & 60.0 & 0 & 0 & 40 & $D / 95 / 1$ & 361 & 1.741 & 31.3 \\
\hline 5 & 8 & 100.0 & 0 & 0 & 0 & $W / 55 / 3$ & 878 & 1.754 & 28.9 \\
\hline 6 & 9 & 6.7 & 0 & 53.3 & 40 & $D / 95 / 3$ & 307 & 1.709 & 31.8 \\
\hline 9 & 10 & 6.7 & 53.3 & 0 & 40 & $W / 95 / 1$ & 244 & 1.665 & 35.2 \\
\hline 1 & 11 & 6.7 & 0 & 53.3 & 40 & $W / 55 / 3$ & 653 & 1.709 & 31.4 \\
\hline 3 & 12 & 100.0 & 0 & 0 & 0 & $D / 55 / 1$ & 750 & 1.760 & 29.9 \\
\hline & $\begin{array}{l}X / Y Y \\
W= \\
D=r\end{array}$ & addi & $\begin{array}{l}\text { le, mo } \\
{ }^{\circ} \mathrm{C} \\
\text { wate } \\
\text { nal w }\end{array}$ & $a d$ & ring & curing & & & \\
\hline
\end{tabular}

\section{LEACHABILITY}

ANS 16.1 leach tests were conducted on DSSF grout samples cured for 1 or 3 months. These tests were conducted to determine relative changes in the leach behavior of DSSF grout as a function of various parameters, rather than to provide direct data for assessing the performance of the grout disposal system. Also, changes in the leaching behavior can provide insight into physical and chemical changes that may be occurring within the grout. The grout samples were leached for 28 to 35 days in deionized water. The leachates were analyzed by ICP for cations and IC for anions. Nitrate and sodium data were evaluated because they were expected to remain mostly within the liquid phase in the grout, where their release would be controlled by diffusion. 
In the calculation of effective diffusion coefficients, the original inventory of species present in the grout samples $\left(A_{0}\right)$ was calculated from analytical data for the starting waste and the dry blend constituents. The following discussion focuses primarily on $\mathrm{NO}_{3}$ and $\mathrm{Na}$ release from the grout samples. A summary of the leachability indices for $\mathrm{Na}$ and $\mathrm{NO}_{3}$ for the DSSF grout samples is shown in Tables 10 and 11 for the Matrix-1 and Matrix-2 samples, respectively. The lowest leachability indices for nitrate and sodium occur for the samples made with undiluted DSSF and cured at $95^{\circ} \mathrm{C}$, as seen in Table 10. Temperature had the greatest effect on the leachability of those samples that contained equal amounts of slag and $f l y$ ash $(F / C=8$ and $S / C=8)$.

The effects of temperature and waste dilution on the nitrate leachability are further illustrated in Figures 1 through 4 , which show the cumulative fraction nitrate leached as a function of the square root of time. The labels in these figures (i.e., Slag. Cement, Fly Ash, and Blend) represent the solids most predominant in the dry blend. For example, "Slag" represents a dry blend of 6.7 wt\% cement, 40 wt\% limestone flour, and 53.3 wt\% slag. "Blend" is close to the reference dry blend and consists of $3.6 \mathrm{wt} \%$ cement, $28.2 \mathrm{wt} \%$ slag, 28.2 wt\% fly ash, and 40 wt\% limestone flour. The curves in Figure 1 illustrate the poor leach resistance of grouts prepared with the various blends using full strength DSSF and curing at $95^{\circ} \mathrm{C}$. In a 11 cases, greater than $60 \%$ of the original $\mathrm{NO}_{3}$ was leached out of the samples in less than 2 days. These results are consistent with previous data (Lokken et a1. 1992a). The rate of $\mathrm{NO}_{3}$ release from all these grouts decreased dramatically after about 3 days as the inventory in the larger accessible pores became depleted.

The effect of curing grouts prepared with undiluted DSSF at $55^{\circ} \mathrm{C}$ on the nitrate leachability is shown in Figure 2. The nitrate leachability is highest for the grouts made with with cement and high fly ash blends and was similar to those cured at $95^{\circ} \mathrm{C}$. The effect of lower curing temperatures is most pronounced for the high slag blend and the blend with equal slag and fly ash contents. The amount of nitrate leached after 28 days decreased from about $70 \%$ for the $95^{\circ} \mathrm{C}$-cured sample to about $20 \%$ for the $55^{\circ} \mathrm{C}$-cured sample.

Figure 3 illustrates the effects of dry blend on the nitrate leachability for grouts prepared with diluted DSSF and cured at $95^{\circ} \mathrm{C}$. The fraction of nitrate leached from these samples is less than for those prepared with 
undiluted DSSF (Figure 1), especially for the blend and high-slag grouts. The percentage of nitrate leached from the high-slag grout prepared with undiluted DSSF was nearly $90 \%$, compared to only $10 \%$ from the grout prepared with diluted DSSF.

Figure 4. shows the cumulative fraction nitrate leached from grout samples prepared with diluted DSSF and cured at $55^{\circ} \mathrm{C}$. The high fly ash grout released nitrate the fastest. with greater than $50 \%$ being leached after 1 day. The blend and high-slag grouts retained nitrate the best, with less than $10 \%$ being leached after 28 days of leaching. The lower curing temperature was beneficial in decreasing nitrate leachability for the blend and the highcement grouts, but was detrimental for the high-fly ash grout.

Temperature also had a large influence on the nitrate and sodium leachability for the Matrix-2 samples cured for 1 month, as seen in Table 11 and Figure 5. The $55^{\circ} \mathrm{C}$-cured samples are represented by trial numbers 4,5 . and 12. After 3 months of curing, the temperature effect was smaller (see Figure 6$)$. The $55^{\circ} \mathrm{C}$-cured samples in Figure 6 are trial numbers 6,8 , and 11 . 
TABLE 10. Average $\mathrm{NO}_{3}$ and $\mathrm{Na}$ Leachability Indices for Matrix-1 DSSF Grout Samples Leached by the ANS 16.1 Procedure (All samples were cured for 1 month)

\begin{tabular}{|c|c|c|c|c|c|c|c|c|c|}
\hline \multirow{2}{*}{$\begin{array}{l}\text { Run } \\
\text { No. }\end{array}$} & \multirow{2}{*}{$\begin{array}{c}\text { Trial } \\
\text { No. }\end{array}$} & \multirow[b]{2}{*}{$\mathrm{F} / \mathrm{C}$} & \multirow[b]{2}{*}{$S / C$} & \multirow[b]{2}{*}{ Dil. } & \multirow{2}{*}{$\begin{array}{l}\text { Temp } \\
{ }^{\circ} \mathrm{C}\end{array}$} & \multicolumn{4}{|c|}{ Leachability Index } \\
\hline & & & & & & $\mathrm{NO}_{3}$ & $S D^{(a)}$ & $\mathrm{Na}$ & SD \\
\hline 15 & 1 & 0 & 0 & $1 x$ & 55 & 6.43 & 0.14 & 6.29 & 0.10 \\
\hline 8 & 2 & 8 & 0 & $1 x$ & 55 & 6.57 & 0.23 & 6.99 & 0.22 \\
\hline 7 & 3 & 0 & 8 & $1 x$ & 55 & 7.17 & 0.03 & 7.08 & 0.05 \\
\hline 4 & 4 & 8 & 8 & $1 x$ & 55 & 8.11 & 0.10 & 8.48 & 0.82 \\
\hline 6 & 5 & 0 & 0 & $100 x$ & 55 & 7.22 & 0.21 & 6.72 & 0.35 \\
\hline 3 & 6 & 8 & 0 & $100 x$ & 55 & 6.42 & 0.49 & 7.75 & 0.38 \\
\hline 2 & 7 & 0 & 8 & $100 x$ & 55 & 9.04 & 0.69 & 9.25 & 0.41 \\
\hline 10 & 8 & 8 & 8 & $100 x$ & 55 & 9.55 & 0.66 & 10.08 & 0.35 \\
\hline 18 & 9 & 0 & 0 & $1 X$ & 95 & 6.30 & 0.32 & 6.01 & 0.29 \\
\hline 19 & 10 & 8 & 0 & $1 X$ & 95 & 6.25 & 0.51 & 6.96 & 0.41 \\
\hline 14 & 11 & 0 & 8 & $1 X$ & 95 & 6.14 & 0.34 & 6.08 & 0.31 \\
\hline 12 & 12 & 8 & 8 & $1 X$ & 95 & 6.32 & 0.40 & 6.69 & 0.37 \\
\hline 11 & 13 & 0 & 0 & $100 x$ & 95 & 7.01 & 0.23 & 6.53 & 0.40 \\
\hline 16 & 14 & 8 & 0 & $100 x$ & 95 & 6.65 & 0.49 & 7.68 & 0.33 \\
\hline 17 & 15 & 0 & 8 & $100 x$ & 95 & 8.95 & 0.43 & 8.48 & 0.26 \\
\hline 13 & 16 & 8 & 8 & $100 x$ & 95 & 8.30 & 0.24 & 8.92 & 0.19 \\
\hline 1 & 17 & 4 & 4 & $10 x$ & 75 & 8.78 & 0.47 & 8.78 & 0.39 \\
\hline 5 & 18 & 4 & 4 & $10 x$ & 75 & 9.03 & 0.37 & 8.92 & 0.28 \\
\hline 9 & 19 & 4 & 4 & $10 x$ & 75 & 9.07 & 0.27 & 8.88 & 0.25 \\
\hline
\end{tabular}

(a) $\mathrm{SD}=$ one standard deviation of 7 leaching intervals 
TABLE 11. Average $\mathrm{NO}_{3}$ and $\mathrm{Na}$ Leachability Indices for Matrix-2 OSSF Grout Samples Leached by the ANS 16.1 Procedure

\begin{tabular}{|c|c|c|c|c|c|c|c|c|c|c|}
\hline \multirow{2}{*}{$\begin{array}{l}\text { Run } \\
\text { No. }\end{array}$} & \multirow{2}{*}{$\begin{array}{c}\text { Trial } \\
\text { No. }\end{array}$} & \multicolumn{4}{|c|}{ Dry Blend Composition, Wt\% } & \multirow{2}{*}{$\begin{array}{l}\text { Curing } \\
\text { Conditions (a) }\end{array}$} & \multicolumn{4}{|c|}{ Leachability Index } \\
\hline & & C & $F$ & $S$ & $L$ & & $\mathrm{NO}_{3}$ & $S D^{(b)}$ & $\mathrm{Na}$ & SD \\
\hline 10 & 1 & 3.6 & 28.2 & 28.2 & 40 & $0 / 95 / 3$ & 6.35 & 0.46 & 6.61 & 0.41 \\
\hline 2 & 2 & 11.1 & 88.9 & 0 & 0 & $W / 95 / 3$ & 6.89 & 0.16 & 7.46 & 0.17 \\
\hline 8 & 3 & 11.1 & 0 & 88.9 & 0 & $W / 95 / 1$ & 6.32 & 0.28 & 6.36 & 0.27 \\
\hline 12 & 4 & 5.8 & 47.1 & 47.1 & 0 & $W / 55 / 1$ & 8.39 & 0.11 & 8.44 & 0.11 \\
\hline 4 & 5 & 3.6 & 28.2 & 28.2 & 40 & $D / 55 / 1$ & 7.95 & 0.06 & 7.95 & 0.09 \\
\hline 11 & 6 & 11.1 & 88.9 & 0 & 0 & $D / 55 / 3$ & 7.07 & 0.12 & 7.49 & 0.14 \\
\hline 7 & 7 & 60.0 & 0 & 0 & 40 & $0 / 95 / 1$ & 6.24 & 0.37 & 6.00 & 0.33 \\
\hline 5 & 8 & 100.0 & 0 & 0 & 0 & $w / 55 / 3$ & 7.09 & 0.04 & 7.01 & 0.04 \\
\hline 6 & 9 & 6.7 & 0 & 53.3 & 40 & $D / 95 / 3$ & 6.12 & 0.39 & 6.12 & 0.35 \\
\hline 9 & 10 & 6.7 & 53.3 & 0 & 40 & $W / 95 / 1$ & 6.41 & 0.49 & 6.76 & 0.45 \\
\hline 1 & 11 & 6.7 & 0 & 53.3 & 40 & $W / 55 / 3$ & 6.63 & 0.09 & 6.67 & 0.08 \\
\hline 3 & 12 & 100.0 & 0 & 0 & 0 & $D / 55 / 1$ & 7.30 & 0.02 & 6.95 & 0.02 \\
\hline b) & $\begin{array}{l}\prod_{W}^{X / Y Y I} \\
D=a \\
S D=n\end{array}$ & $\begin{array}{l}\text { uring } \\
\text { nperatu } \\
\text { ddition } \\
\text { o addit }\end{array}$ & $\begin{array}{l}\text { e, mo } \\
\text { ' }{ }^{\circ} \mathrm{C} \\
\text { wate } \\
\text { nal w }\end{array}$ & $r$ add & ring & curing & & & & \\
\hline
\end{tabular}




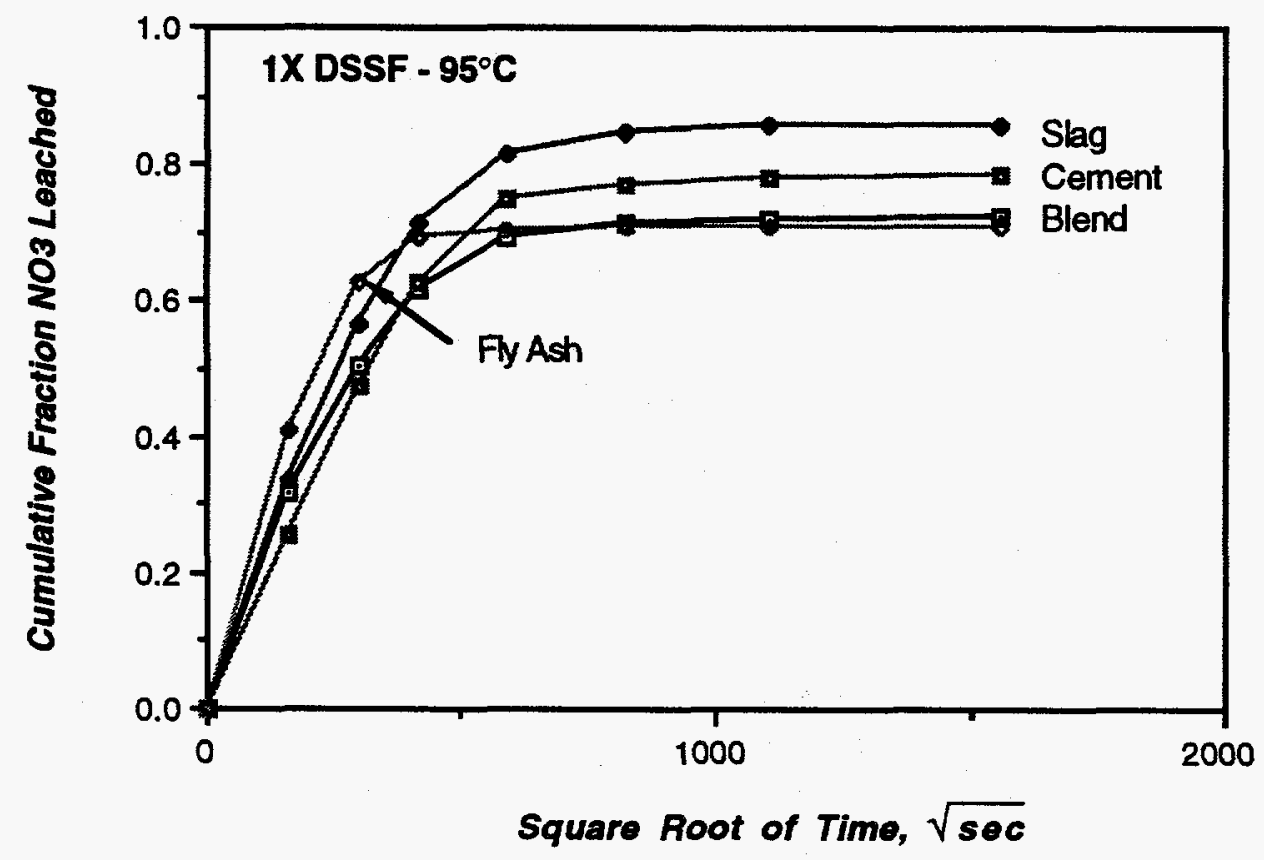

FIGURE 1. Cumulative Fraction of Nitrate Leached from DSSF Grout Samples Prepared with Ful1-Strength DSSF and Cured at $95^{\circ} \mathrm{C}$

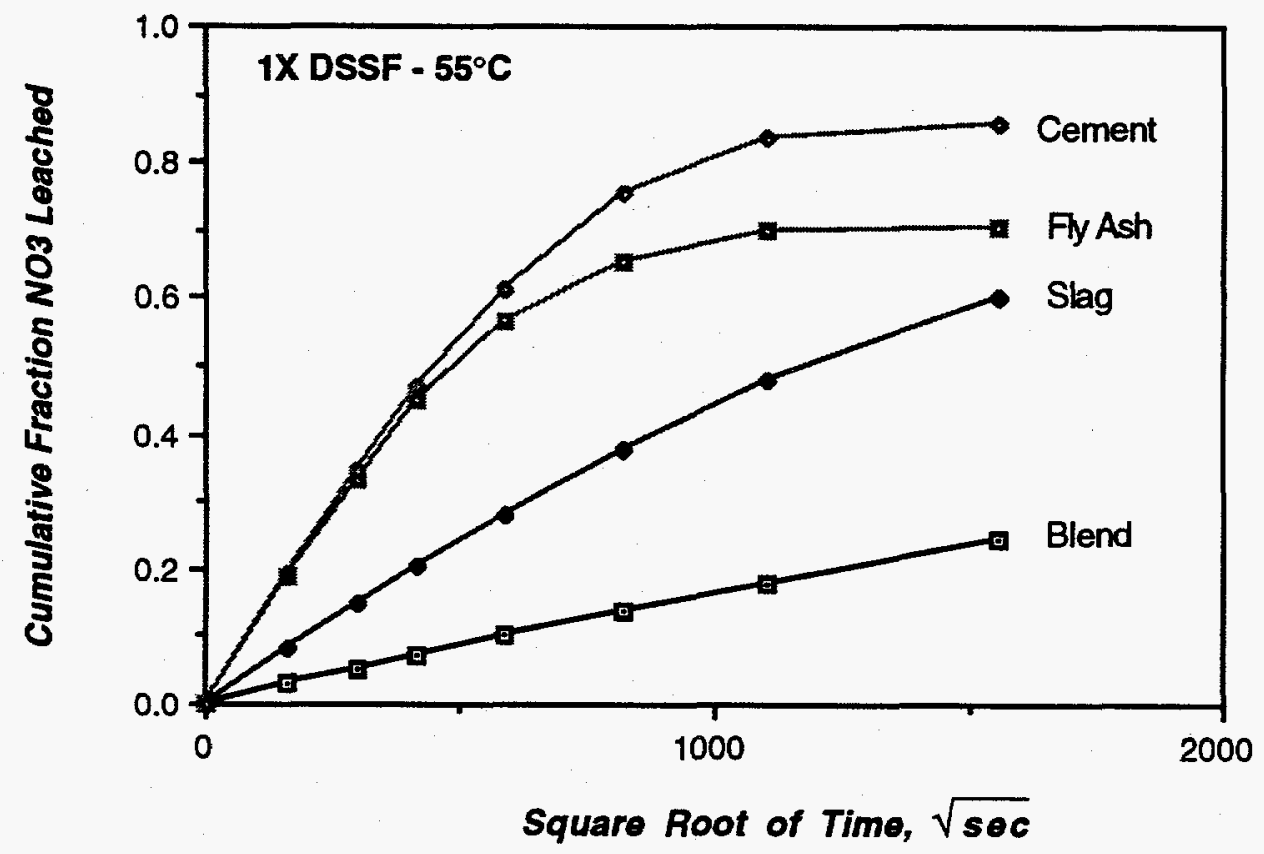

FIGURE 2. Cumulative Fraction of Nitrate Leached from DSSF Grout Samples Prepared with Ful1-Strength DSSF and Cured at $55^{\circ} \mathrm{C}$ 


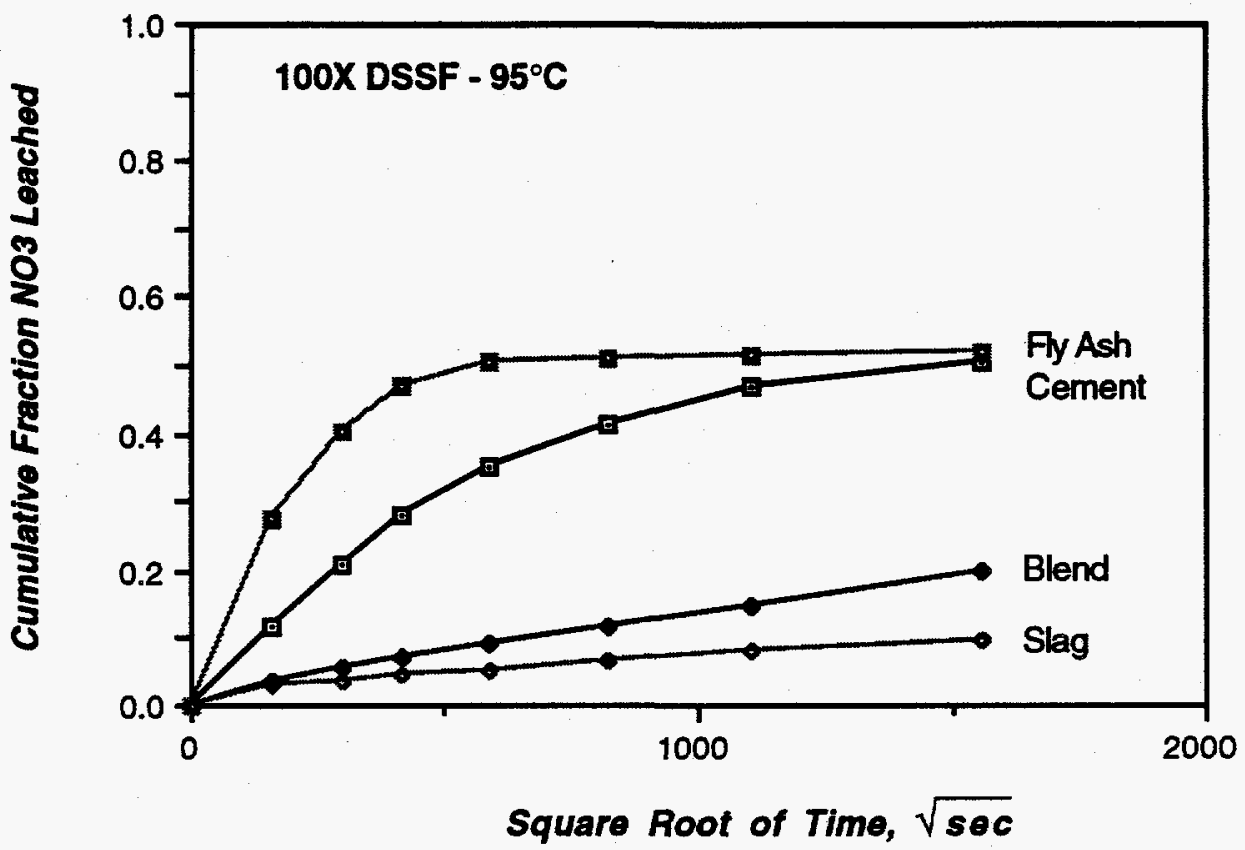

FIGURE 3. Cumulative Fraction of Nitrate Leached from DSSF Grout Samples Prepared with Dilute DSSF and Cured at $95^{\circ} \mathrm{C}$

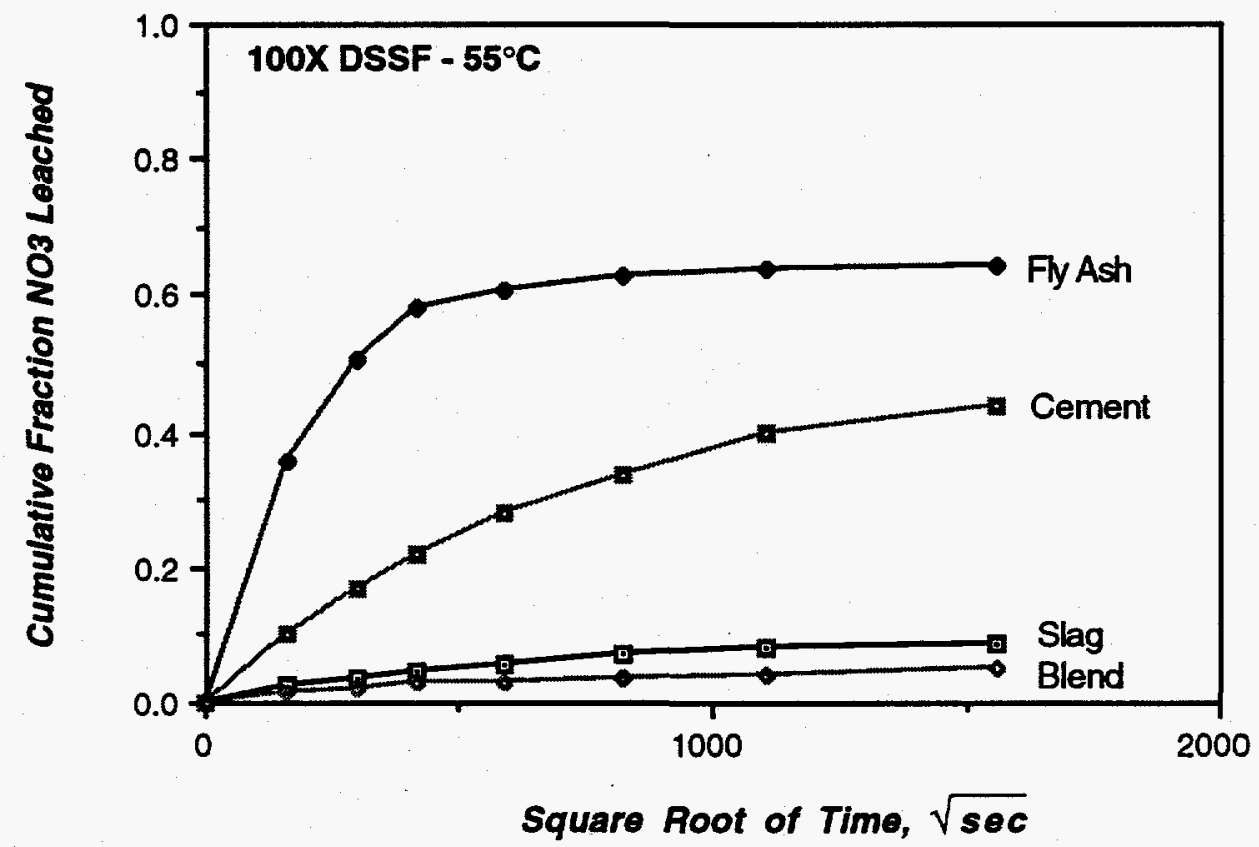

FIGURE 4. Cumulative Fraction of Nitrate Leached from DSSF Grout Samples Prepared with Dilute DSSF and Cured at $55^{\circ} \mathrm{C}$ 


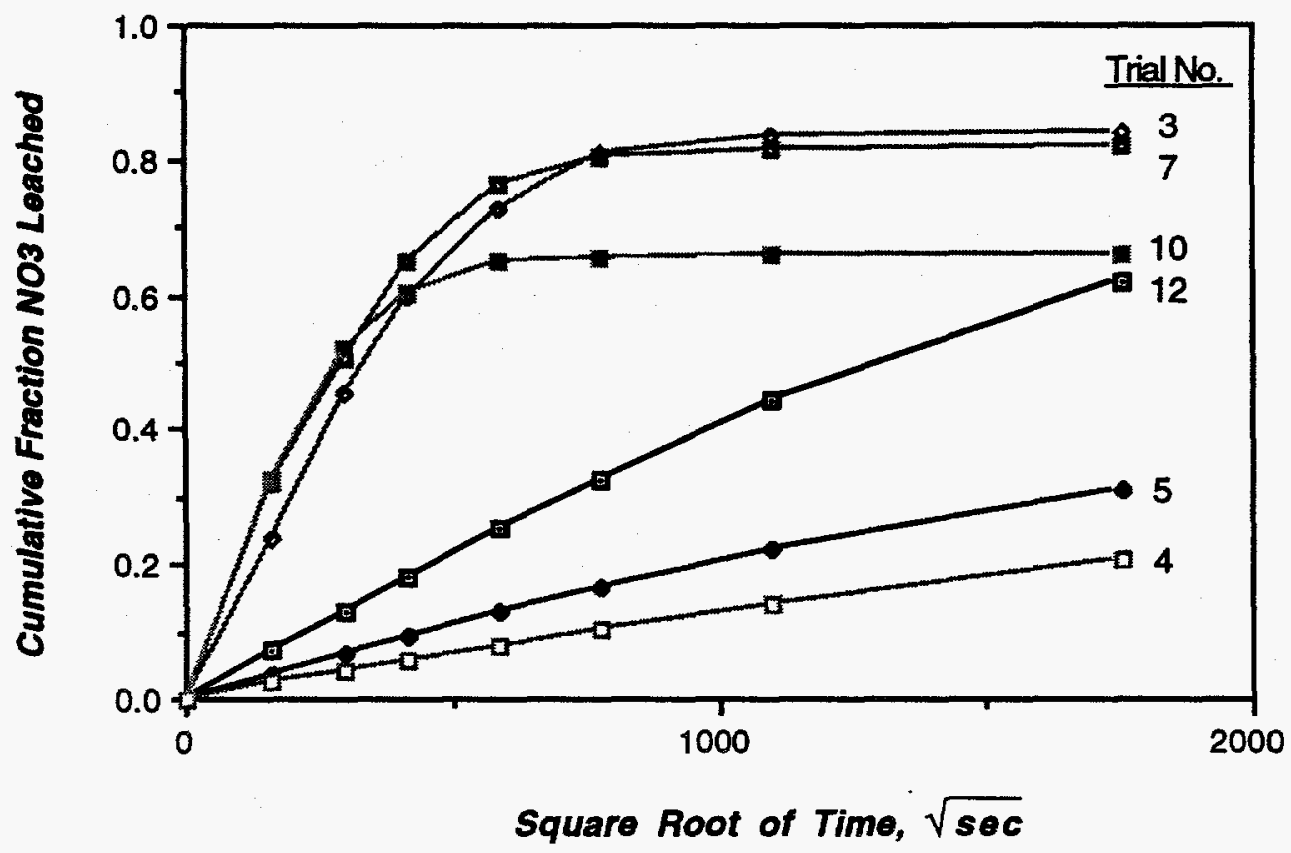

FIGURE 5. Cumulative Fraction of Nitrate Leached from Matrix-2 DSSF Grout Samples Cured for 1 Month

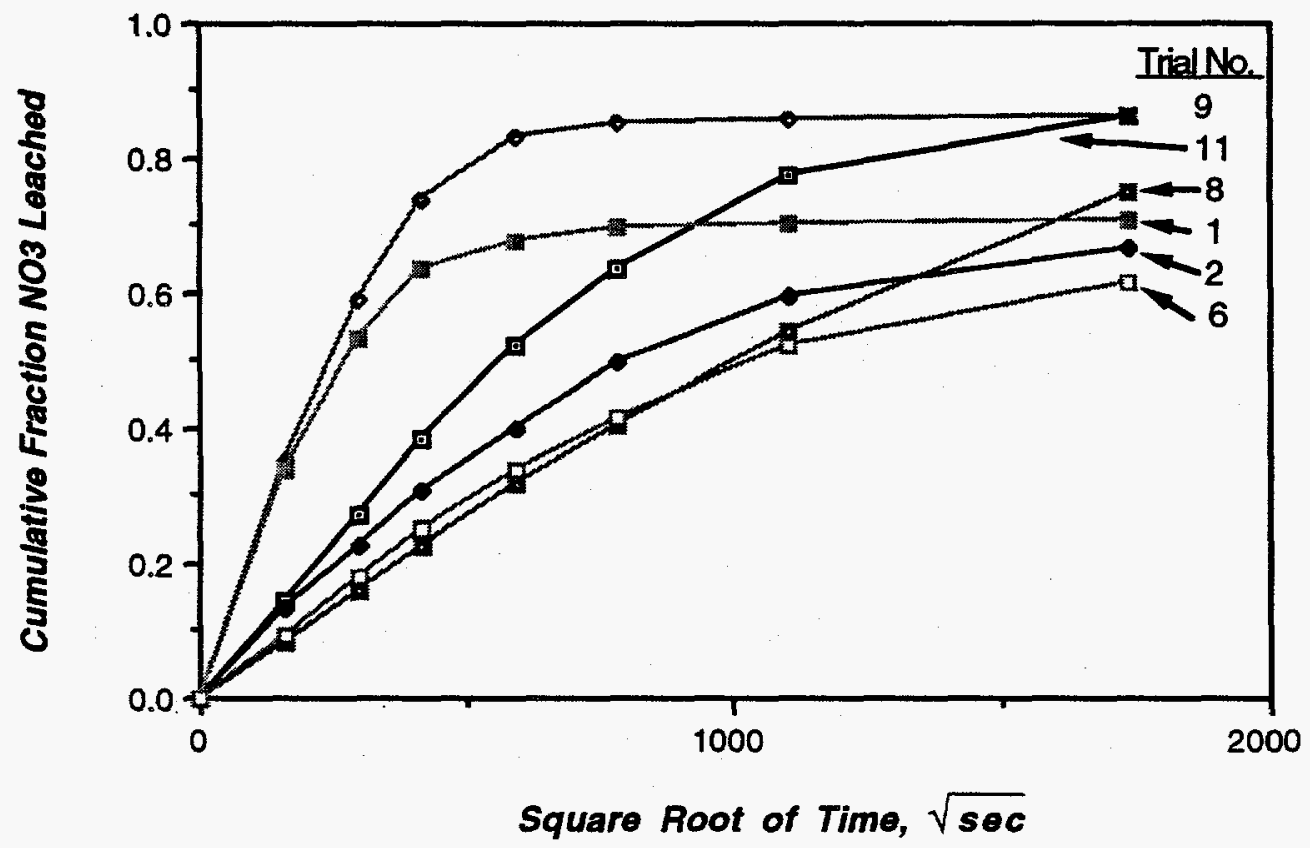

FIGURE 6. Cumulative Fraction of Nitrate Leached from Matrix-2 DSSF Grout Samples Cured for 3 Months 


\section{PORE SIZE DISTRIBUTION}

Mercury intrusion porosimetry was conducted on selected grout samples from the matrix-1 group to determine whether the large changes in leach resistance could be correlated with changes in the distribution of pores within the grout. Figures 7 and 8 show the cumulative volume intruded vs. pore diameter for grout samples prepared with undiluted DSSF and cured at $55^{\circ} \mathrm{C}$ and $95^{\circ} \mathrm{C}$, respectively. There do not appear to be any large, clear correlations between the nitrate leachability (Figures 1 and 2 ) and the pore size distributions. For example, comparing the curves of the cement and the fly ash grouts in Figure 2 shows a relatively small difference in the amount of nitrate leached. This would suggest similar pore size distributions for these two grouts: however, as seen in Figure 7 , the fly ash grout contains a greater number of larger pores and more total intruded volume than the cement grout. Except for the fly ash grouts, increased curing temperature did not appear to alter the pore size distributions (see figure 8 ). The pore size distribution of the fly ash grout shifted toward larger pores as curing temperature increased, i.e.. the curve shifted to the left.

Figure 9 shows the pore size distribution of DSSF grout samples prepared with 3.5 wt\% cement, 28.2 wt\% slag, 28.2 wt\% fly ash, and 40 wt\% 1 imestone flour. Waste dilution has a large influence on the resultant pore size distributions of these grouts. For grouts prepared with diluted DSSF, increased curing temperature resulted in a shift in the pore size distribution toward slightly larger pores and increased total intruded volume. Based on these data, it is suspected that the measured pore sizes of the grouts prepared with undiluted DSSF is not representative of the actual pores that would contain dissolved species during the leach tests. The samples for porosimetry were dried prior to testing, resulting in the precipitation of salts which may have filled some of the larger pores. One possible method of obtaining more representative pore size distributions in the future would be to leach the salts from the grouts prior to testing. A potential problem with this method, however, is that the structure of the grout matrix could change, depending on the solubility of the reaction products. 


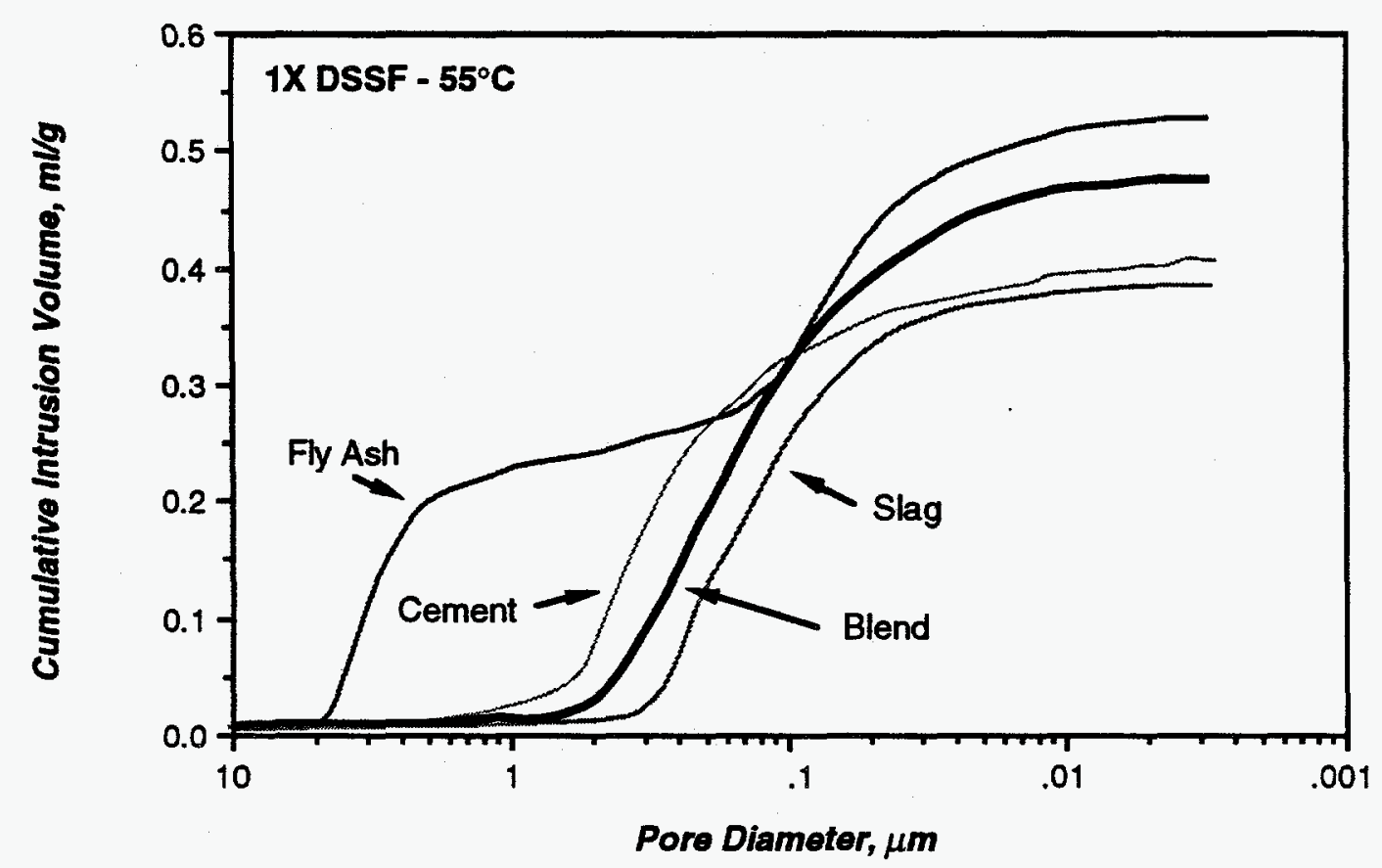

FIGURE 7. Pore Size Distribution of DSSF Grout Samples Prepared with Undiluted DSSF and Cured at $55^{\circ} \mathrm{C}$

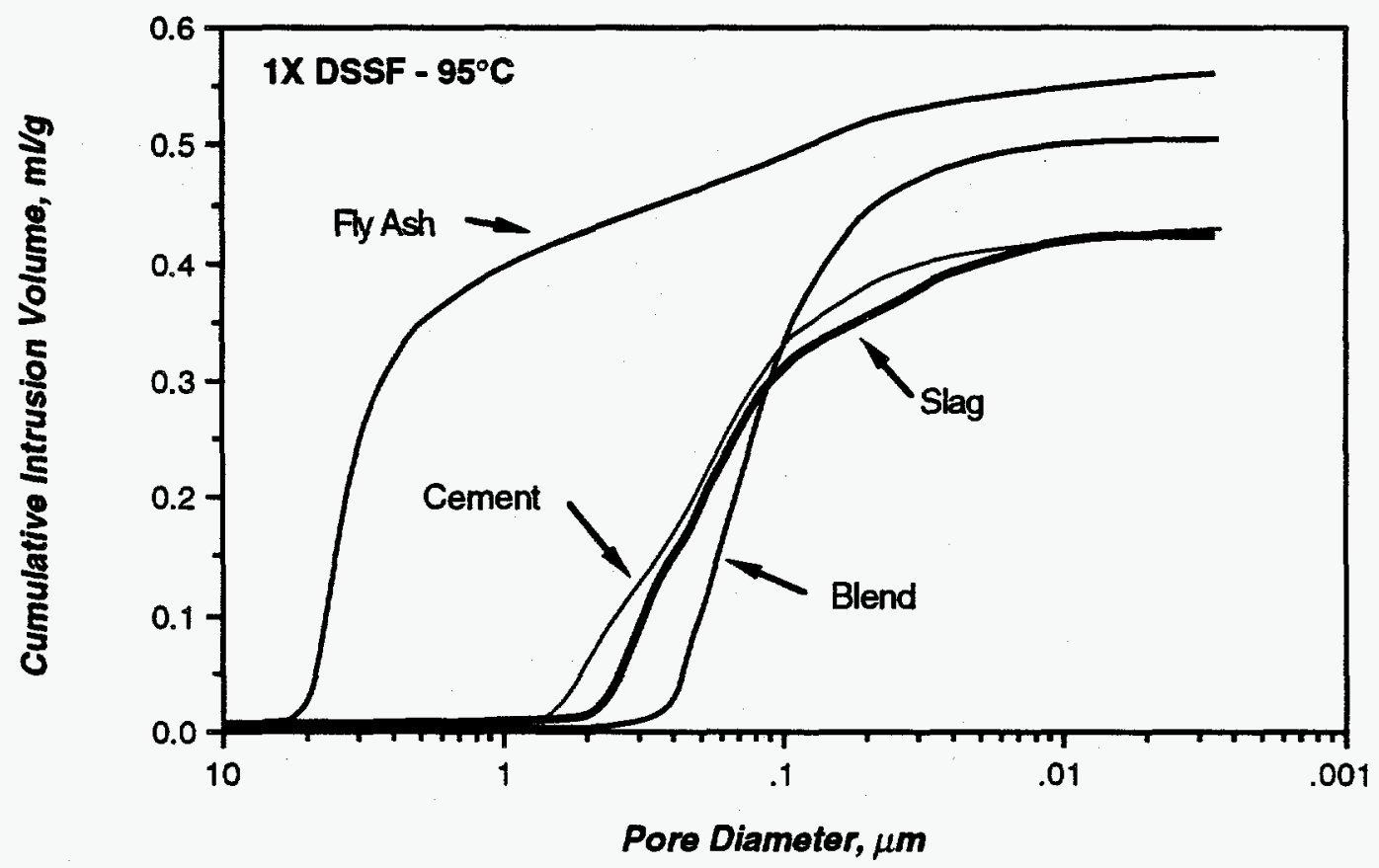

FIGURE 8. Pore Size Distribution of DSSF Grout Samples Prepared with Undiluted DSSF and Cured at $95^{\circ} \mathrm{C}$ 


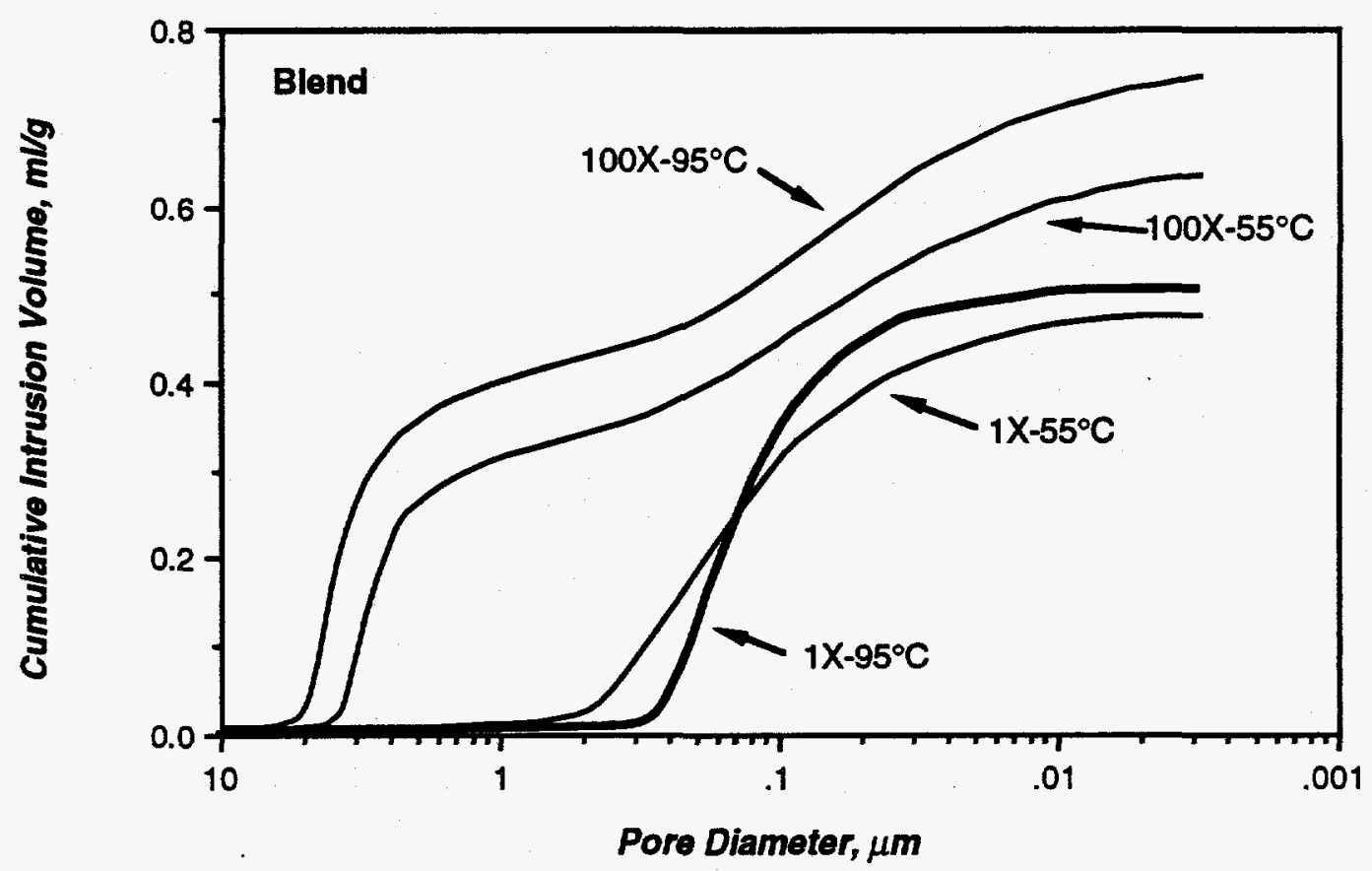

FIGURE 9. Pore Size Distribution of DSSF Grout Samples Prepared with 3.6 wt\% Cement, 28.2 wt\% Fly Ash, 28.2 wt\% Slag, and 40 wt\% Limestone Flour

\section{STATISTICAL EVALUATION}

The experimental matrices used in these studies were designed to allow statistical evaluation of the data using multiple regression analysis. Matrix 1 was a two-level, fourth-order factorial design for determining the main effects of fly ash-to-cement ratio, slag-to-cement ratio. DSSF waste dilution, and curing temperature on selected properties of the grouts. This design also allows the determination of interactions between factors and, because three replicates of the center of the factor space were done, an estimate of curvature (i.e., deviation from linearity) can be made. Matrix 2 was a Plackett-Burman screening design, which allows only main effects to be estimated.

The results of the statistical evaluation of the matrix-1 data are listed in Table 12. The effects listed are significant at a $95 \%$ confidence level. Unassigned factor effects of the three-way and four-way interactions were used to determine the confidence intervals. The main effects of $F / C, S / C$, dilution, and temperature are listed in the first four columns and the two-way interactions between these factors are listed in the last six columns. The 
effects are listed in order of magnitude, with a "1" having the largest effect, and whether the effect was positive or negative. Dilution had the largest effect on the slurry properties, i.e., critical flow rate, slurry density, and drainable liquids. The fly ash/cement ratio also had significant effects on the slurry properties. There were also two 2-way interactions affecting the slurry density and drainable liquids, the most significant including dilution. There were no significant effects (at the $95 \%$ confidence level) of any of the factors on the compressive strength values, primarily because the error values were large. Bulk density and evaporable water content were affected by the same factors and two-way interactions, but in opposite directions. The slag/cement ratio and dilution had the largest effect on the sodium and nitrate leachability. These properties were the only ones in which curing temperature had a significant effect. There were also two-way interactions between $S / C$ and dilution and between dilution and temperature. These effects and the interactions were also evident in figures 1 to 4 , as discussed above. Based on the above discussions, the two most significant factors affecting the grout properties were the slag/cement ratio and waste dilution. Interactions between these two factors were also significant, indicating that reactions between the slag and the waste appear to dominate the properties of DSSF grouts. A summary of the multiple regression analyses is 1 isted in the Appendix.

An analysis was also conducted on the matrix-2 data; however, very few significant effects were observed. A summary of the multiple regression analyses is listed in the Appendix. 
TABLE 12. Results from the Statistical Evaluation of Main Effects and Two-Way Interactions for Matrix-1 Data(a)

\begin{tabular}{|c|c|c|c|c|c|c|c|c|c|c|}
\hline & $\mathrm{F} / \mathrm{C}$ & $S / C$ & Dil & Temp & \multicolumn{6}{|c|}{ Interactions } \\
\hline & $\times 1$ & $\times 2$ & $\times 3$ & $\times 4$ & $\times 1 \times 2$ & $\times 1 \times 3$ & $\times 1 \times 4$ & $\times 2 \times 3$ & $\times 2 \times 4$ & $\times 3 \times 4$ \\
\hline $\begin{array}{l}\text { Critical } \\
\text { Flow Rate }\end{array}$ & $\begin{array}{l}2(b) \\
-(c)\end{array}$ & & $\begin{array}{l}1 \\
-\end{array}$ & & & & & & & \\
\hline $\begin{array}{l}\text { Slurry } \\
\text { Density }\end{array}$ & $\begin{array}{l}2 \\
-\end{array}$ & $\begin{array}{l}4 \\
-\end{array}$ & $\begin{array}{l}1 \\
-\end{array}$ & & $\begin{array}{l}3 \\
+\end{array}$ & $\begin{array}{r}5 \\
+\end{array}$ & & & & \\
\hline $\begin{array}{l}\text { Drainable } \\
\text { Liquid }\end{array}$ & $\begin{array}{l}3 \\
+\end{array}$ & $\begin{array}{l}2 \\
-\end{array}$ & $\begin{array}{r}1 \\
+\end{array}$ & & & $\begin{array}{r}3 \\
+ \\
\end{array}$ & & $\begin{array}{l}2 \\
-\end{array}$ & & \\
\hline $\begin{array}{l}\text { Compressive } \\
\text { Strength } \\
\end{array}$ & & & & & & & & & & \\
\hline $\begin{array}{l}\text { Bulk } \\
\text { Density }\end{array}$ & 6 & 1 & $\begin{array}{l}3 \\
-\end{array}$ & & $\begin{array}{r}5 \\
+\end{array}$ & $\begin{array}{r}4 \\
+ \\
\end{array}$ & & 2 & & \\
\hline $\begin{array}{l}\text { Evaporable } \\
\text { Water }\end{array}$ & $\begin{array}{l}6 \\
+\end{array}$ & $\begin{array}{l}2 \\
+ \\
\end{array}$ & $\begin{array}{l}3 \\
+\end{array}$ & & 5 & $\begin{array}{l}4 \\
-\end{array}$ & & $\begin{array}{l}1 \\
+\end{array}$ & & \\
\hline $\begin{array}{l}\mathrm{NO}_{3} \text { Leach } \\
\text { Index }\end{array}$ & & $\begin{array}{l}1 \\
+\end{array}$ & $\begin{array}{l}2 \\
+\end{array}$ & $\begin{array}{l}4 \\
-\end{array}$ & & & & $\begin{array}{l}3 \\
+\end{array}$ & $\begin{array}{l}5 \\
-\end{array}$ & \\
\hline $\begin{array}{l}\text { Na Leach } \\
\text { Index }\end{array}$ & $\begin{array}{l}3 \\
+\end{array}$ & $\begin{array}{l}2 \\
+\end{array}$ & $\begin{array}{l}1 \\
+\end{array}$ & $\begin{array}{l}5 \\
-\end{array}$ & & & & $\begin{array}{l}4 \\
+\end{array}$ & $\begin{array}{l}6 \\
-\end{array}$ & \\
\hline
\end{tabular}

(a) Effects are significant at a 95\% confidence level. Effects were calculated using a 2-level, 4th order factorial design. Unassigned factor effects using three-way and four-way interactions were used to determine confidence intervals.

(b) Numbers represent the order of the effect, i.e., 1 represents the largest effect

(c) + represents a positive effect; - represents a negative effect 


\section{REFERENCES}

American Nuclear Society (ANS). 1986. Measurement of the Leachability of Solidified Low-Level Radioactive Wastes by a Short-Term Test Procedure. ANSI/ANS 16.1-1986, American Nuclear Society, LaGrange Park, Illinois.

Claghorn, R. D. 1987. Compositional Limits for Grout Feed: Double-Shell Slurry and Retrieved Double-Shell Slurry Formulation Experiments. RHO-RE-EV96. Rockwell Hanford Operations, Richland, Washington.

de Laguna, W. 1966. "Disposal of Radioactive Wastes by Hydraulic Fracturing: Part I." Nuclear Engineering and Design. 3. pp. 338-352.

Fow, C. L.. D. H. Mitchel1, R. L. Treat, and C. R. Hymas. 1987. Pilot-Scale Grout Production Test with a Simulated Low-Level Waste. PNL-6148. Pacific Northwest Laboratory, Richland, Washington.

Guymon, R. H., L. D. Vanselow, and G. D. Campbe11. 1988. "The Grout Treatment Facility - - Processing Facilities for Low-Level Waste Immobilization and Dis posal." in Proceedings of the International Topical Meeting on Nuclear and Hazardous Waste Management. SPECTRUM '88, held September 11-15, 1988, Pasco, Washington. American Nuclear Society, Inc., La Grange Park. IL. pp. 95-98.

Langton, C. A. 1988. "Metal Toxicity Evaluation of Savannah River Plant Saltstone - Comparison of EP and TCLP Test Results," in Proceedings of Waste Management '88, held February 28 - March 3, 1988, Tucson, Arizona.

Lokken, R. 0., P. F. C. Martin, W. M. Bowen, H. Harty, and R. L. Treat. 1987. Variability in Properties of Grouted Phosphate/Sulfate N-Reactor Waste. PNL6030. Pacific Northwest Laboratory. Richland. Washington.

Lokken, R. O. and D. H. Mitchell. 1988. "Pilot-Scale Grout Production using a Simulated Low-Level Waste: Process Description and Product Characterization," in Proceedings of the International Topical Meeting on Nuclear and Hazardous Waste Management. SPECTRUM '88, held September 11-15, 1988, Pasco, Washington. American Nuclear Society, Inc., La Grange Park. Illinois. pp. 234-236.

Lokken, R. 0., M. A. Reimus, P. F. C. Martin and S. E. Geldart. 1988. Characterization of a Simulated Low-Level Waste Grout Produced in a PilotScale Test. PNL-6396. Pacific Northwest Laboratory, Richland, Washington.

Lokken, R. O., J. W. Shade, P. F. C. Martin. 1989. "Effect of Curing Temperature on the Properties of Cementitious Waste Forms". PNL-SA-17052. Scientific Basis for Nuclear Waste Management XIII. Mat. Res. Soc. Symp. Proc. Vol 176. Edited by V. M. Oversby and P. W. Brown, Materials Research Society, Pittsburgh. Pennsylvania, pp. 23-29.

Lokken, R. 0.. P. F. C. Martin, and J. W. Shade. 1992a. Durability of Double-Shell Tank Waste Grouts. PNL-7835, Pacific Northwest Laboratory. Richland, Washington. 
Lokken, R. 0., P. F. C. Martin, and J. W. Shade. 1992b. Characterization of a Double-Shell Slurry Feed Grout Produced in a Pilot-Scale Test. PNL-7979, Pacific Northwest Laboratory. Richland. Washington.

Martin. P. F. C. and R. 0. Lokken. 1992. Characterization of a Low-Level Radioactive Waste Grout: Sampling and Test Results. PNL-8067. Pacific Northwest Laboratory, Richland, Washington.

Serne, R. J.. W. J. Martin. S. B. McLaurine, S. P. Airhart, V. L. LeGore, and R. L. Treat. 1987. Laboratory Leach Tests of PSW Grout and Leachate Adsorption Tests using Hanford Sediment. PNL-6019. Pacific Northwest Laboratory, Richland, Washington.

Sewart, G. H.. W. T. Ferris, D. H. Huizenga, A. H. McMakin, G. P. Streile, and R. L. Treat. 1987. Long-Term Performance Assessment of Grouted Phosphate/Sulfate Waste From $N$ Reactor Operations. PNL-6152, Pacific Northwest Laboratory, Richland, Washington.

Weeren, H. 0. 1976. An Evaluation of Waste Disposal by Shale Fracturing. ORNL-TM-5209, Oak Ridge National Laboratory. Oak Ridge. Tennessee.

Wilhite, E. L., C. A. Langton, H. F. Sturm, R. L. Hooker, and E. S. Occhipinti. 1988. "Saltstone Processing Startup at the Savannah River Plant." in Proceedings of the International Topical Meeting on Nuclear and Hazardous Waste Management. SPECTRUM '88, held September 11-15, 1988, Pasco. Washington. American Nuclear Society. Inc., La Grange Park, Illinois. pp. $99-$ 101 


\section{APPENDIX}

SUMMARIES OF THE

MULTIPLE REGRESSION ANALYSES 


\begin{tabular}{|c|c|c|c|c|c|}
\hline \multicolumn{6}{|c|}{ Multiple Regression $Y_{1}:$ CFR $4 X$ variables } \\
\hline Count: & $\mathrm{R}:$ & & R-squared: & Adj. R-squared: & RMS Residual: \\
\hline 16 & .914 & & .836 & .777 & 3.93 \\
\hline \multicolumn{6}{|c|}{ Analysis of Variance Table } \\
\hline REGRESSION & 4 & & 867.26 & 216.815 & 14.04 \\
\hline RESIDUAL & 11 & & 169.875 & 15.443 & $p=.0003$ \\
\hline TOTAL & 15 & & 1037.135 & & \\
\hline \multicolumn{6}{|c|}{ Residual Information Table } \\
\hline \multicolumn{2}{|c|}{296.54} & 8 & 8 & 1.746 & \\
\hline
\end{tabular}

\begin{tabular}{|c|c|c|c|c|c|}
\hline \multicolumn{6}{|c|}{ Multiple Regression $Y_{1}: C F R \quad 4 X$ variables } \\
\hline \multicolumn{6}{|c|}{ Beta Coefficient Table } \\
\hline Variable: & Coofficient: & Std. Err.: & Std. Coeff.: & t-Value: & Probability: \\
\hline INTERCEPT & 24.175 & & & & \\
\hline F/C & -1.261 & .246 & -.626 & 5.133 & .0003 \\
\hline $\mathrm{S} / \mathrm{C}$ & .313 & .246 & .156 & 1.276 & .2282 \\
\hline Dil & -.105 & .02 & -.647 & 5.301 & .0003 \\
\hline Temp & .015 & .049 & .037 & .3 & .7696 \\
\hline
\end{tabular}

\begin{tabular}{|c|c|c|c|c|c|}
\hline \multicolumn{6}{|c|}{ Multiple Regression $Y_{1}: C F R \quad 4 X$ variables } \\
\hline \multicolumn{6}{|c|}{ Confidence Intervals and Partial F Table } \\
\hline Variable: & 95\% Lower: & 95\% Upper: & 90\% Lower: & $90 \%$ Upper: & Partial F: \\
\hline \multicolumn{6}{|l|}{ INTERCEPT } \\
\hline $\mathrm{F} / \mathrm{C}$ & -1.801 & -.72 & -1.702 &. .819 & 26.344 \\
\hline S/C & -.227 & .854 & -.128 & .755 & 1.629 \\
\hline Dil & -.149 &. .062 & -.141 & .07 & 28.096 \\
\hline Temp & -.093 & .123 & .073 & .103 & .09 \\
\hline
\end{tabular}
IABLEAl. Multiple Regression Analysis for Critical Flow Rate for the
Matrix-1 Grout Samples 


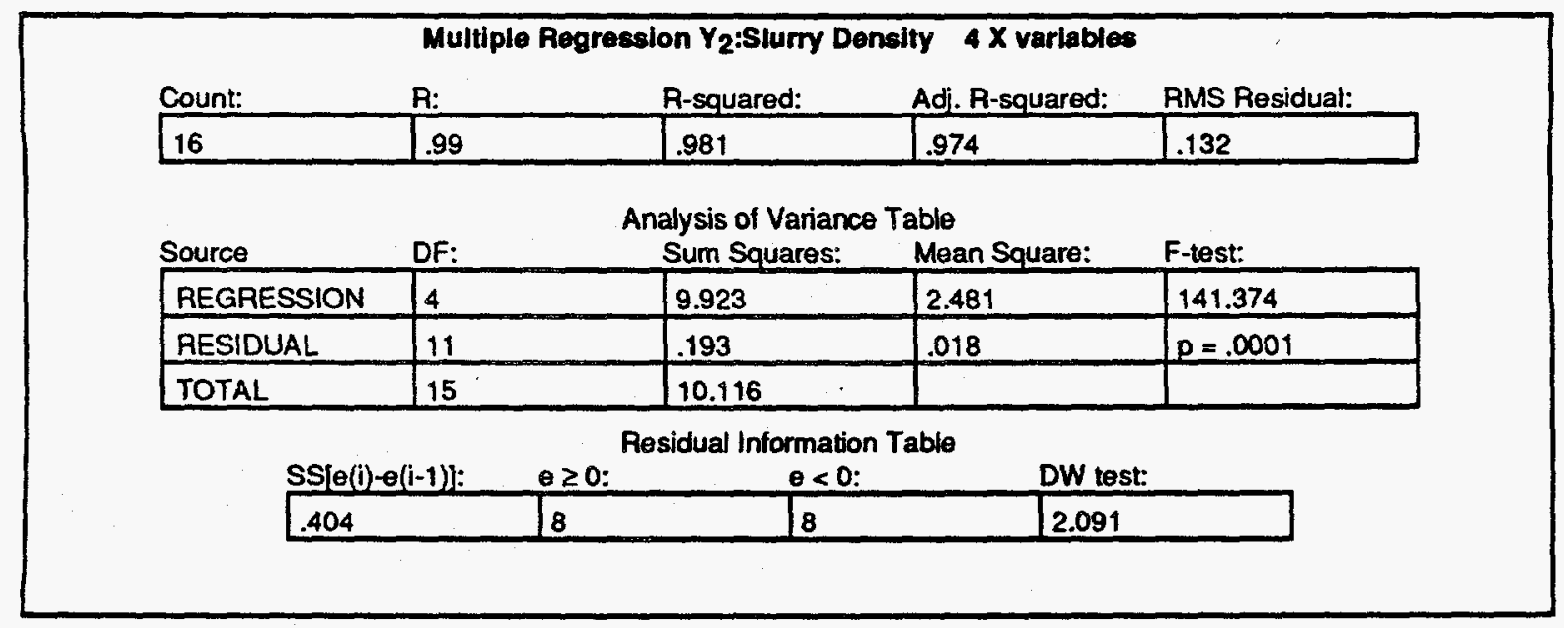

\begin{tabular}{|c|c|c|c|c|c|}
\hline \multicolumn{6}{|c|}{ Multiple Regression $Y_{2}$ :Slurry Density $4 X$ varlables } \\
\hline \multirow[b]{2}{*}{ Variable: } & \multicolumn{4}{|c|}{ Beta Coefficient Table } & \multirow[b]{2}{*}{ Probability: } \\
\hline & Coefficient: & Std. Err:: & Std. Coeff:: & i-Value: & \\
\hline INTERCEPT & 14.275 & & & & \\
\hline F/C & -.062 & .008 & -.312 & 7.493 & .0001 \\
\hline $\mathrm{S} / \mathrm{C}$ & -.007 & .008 & -.035 & .849 & .4138 \\
\hline Dil & .015 & .001 &. .939 & 22.553 & .0001 \\
\hline Temp & $3.125 E-5$ & .002 & .001 & .019 & .9853 \\
\hline
\end{tabular}

\begin{tabular}{|c|c|c|c|c|c|}
\hline \multicolumn{6}{|c|}{ Multiple Regression $Y_{2}$ :Slumy Density $4 X$ varlabies } \\
\hline \multicolumn{6}{|c|}{ Confidence Intervals and Partial F Table } \\
\hline Variable: & 95\% Lower: & 95\% Upper: & 90\% Lower: & $90 \%$ Upper: & Partial F: \\
\hline \multicolumn{6}{|l|}{ INTERCEPT } \\
\hline F/C & -.08 & -.044 & -.077 &. .047 & 56.138 \\
\hline S/C & -.025 & .011 & -.022 & .008 & .721 \\
\hline Dil & -.017 &. .014 & -.016 &. .014 & 508.638 \\
\hline Temp &. .004 & .004 & -.003 & .003 & $3.562 E-4$ \\
\hline
\end{tabular}

IABLEA2. Multiple Regression Analysis for Slurry Density for the Matrix-1 Grout Samples 


\begin{tabular}{|c|c|c|c|c|c|}
\hline \multicolumn{6}{|c|}{ Multiple Regression Y3:Shrinkage $4 X$ variables } \\
\hline Count: & R: & & R-squared: & Adi. R-squared: & RMS Residual: \\
\hline 16 & .993 & & .987 & .982 & .579 \\
\hline \multicolumn{6}{|c|}{ Analysis of Variance Table } \\
\hline REGRESSION & 4 & & 276.75 & 69.188 & 206.39 \\
\hline RESIDUAL & 11 & & 3.687 & .335 & $p=.0001$ \\
\hline TOTAL & 15 & & 280.438 & & \\
\hline \multicolumn{6}{|c|}{ 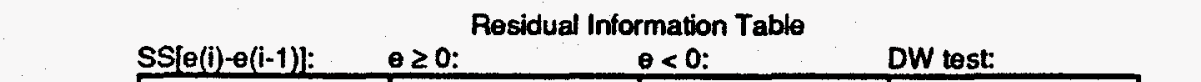 } \\
\hline \multicolumn{2}{|l|}{1.906} & 7 & 9 & .517 & \\
\hline
\end{tabular}

\begin{tabular}{|c|c|c|c|c|c|}
\hline \multicolumn{6}{|c|}{ Multiple Regression Y3:Shrinkage $4 X$ variables } \\
\hline \multicolumn{6}{|c|}{ Beta Coefficient Table } \\
\hline Variable: & Coefficient: & Sid. Err.: & Std. Coeff.: & t-Value: & Probability: \\
\hline INTERCEPT & -8.987 & & & & \\
\hline F/C & .109 & .036 & .105 & 3.023 & .0116 \\
\hline $\mathrm{S} / \mathrm{C}$ & .203 & .036 & .194 & 5.613 & .0002 \\
\hline Dil & .034 & .003 & .403 & 11.658 & .0001 \\
\hline Temp & .184 & .007 & .881 & 25.475 & .0001 \\
\hline
\end{tabular}

\begin{tabular}{|c|c|c|c|c|c|}
\hline \multicolumn{6}{|c|}{ Multiple Regression $Y_{3}$ :Shrinkage $4 \times$ variables } \\
\hline \multirow[b]{2}{*}{ Variable: } & \multicolumn{4}{|c|}{ Confidence Intervals and Partial F Table } & \multirow[b]{2}{*}{ Parial F: } \\
\hline & 95\% Lower: & 95\% Upper: & 90\% Lower: & $90 \%$ Upper: & \\
\hline \multicolumn{6}{|c|}{ INTERCEPT } \\
\hline F/C & .03 & .189 & .044 & .174 & 9.136 \\
\hline S/C & .123 & .283 & .138 & .268 & 31.508 \\
\hline Dil & .028 & .041 & .029 & .039 & 135.915 \\
\hline Temp : & .168 & .2 & .171 & .197 & 649 \\
\hline
\end{tabular}

IABLEA3. Multiple Regression Analysis for Shrinkage for the Matrix-1 Grout Samples 


\begin{tabular}{|c|c|c|c|c|c|}
\hline \multicolumn{6}{|c|}{ Multiple Regression Y4:Drainables $4 \times$ variables } \\
\hline Count: & R: & & R-squared: & Adj. R-squared: & RMS Residual: \\
\hline 16 & .902 & & .814 & .747 & 5.725 \\
\hline \multicolumn{6}{|c|}{ Analysis of Variance Table } \\
\hline REGRESSION & 4 & & 1579.152 & 394.788 & 12.044 \\
\hline RESIDUAL & 11 & & 360.562 & 32.778 & $p=.0005$ \\
\hline TOTAL & 15 & & 1939.714 & & \\
\hline \multicolumn{6}{|c|}{$\theta \geq 0: \quad \begin{array}{c}\text { Residual Information Table } \\
\theta<0:\end{array}$} \\
\hline \multicolumn{2}{|c|}{935.914} & 8 & 8 & 2.59 & \\
\hline
\end{tabular}

\begin{tabular}{|c|c|c|c|c|c|}
\hline \multicolumn{6}{|c|}{ Multiple Regression $Y_{4}:$ Drainables $4 \times$ variables } \\
\hline Variable: & Coefficient: & Std. Err.: & Std. Coeff.: & t-Value: & Probability: \\
\hline INTERCEPT & 1.291 & & & & \\
\hline F/C & .68 & .358 & .247 & 1.899 & .084 \\
\hline $\mathrm{S} / \mathrm{C}$ &. .97 & .358 & -.353 & 2.712 & .0202 \\
\hline Dil & .176 & .029 & .793 & 6.1 & .0001 \\
\hline Temp & -.004 & .072 & -.007 & .057 & .9557 \\
\hline
\end{tabular}

\begin{tabular}{|c|c|c|c|c|c|}
\hline \multicolumn{6}{|c|}{ Multiple Regression $Y_{4}$ :Drainables $4 \times$ variables } \\
\hline \multicolumn{6}{|c|}{ Confidence Intervals and Partial F Table } \\
\hline Variable: & 95\% Lower: & 95\% Upper: & 90\% Lower: & 90\% Upper: & Partial F: \\
\hline \multicolumn{6}{|l|}{ INTERCEPT } \\
\hline F/C & -.108 & 1.467 & .037 & 1.322 & 3.608 \\
\hline SIC & -1.758 & .183 & -1.613 & -.328 & 7.353 \\
\hline Dil & .113 & .24 & .124 & .228 & 37.212 \\
\hline Temp & -.162 & .153 & -.133 & .124 & .003 \\
\hline
\end{tabular}

IABLE A4. Multiple Regression Analysis for Drainable Liquids for the Matrix-1 Grout Samples 


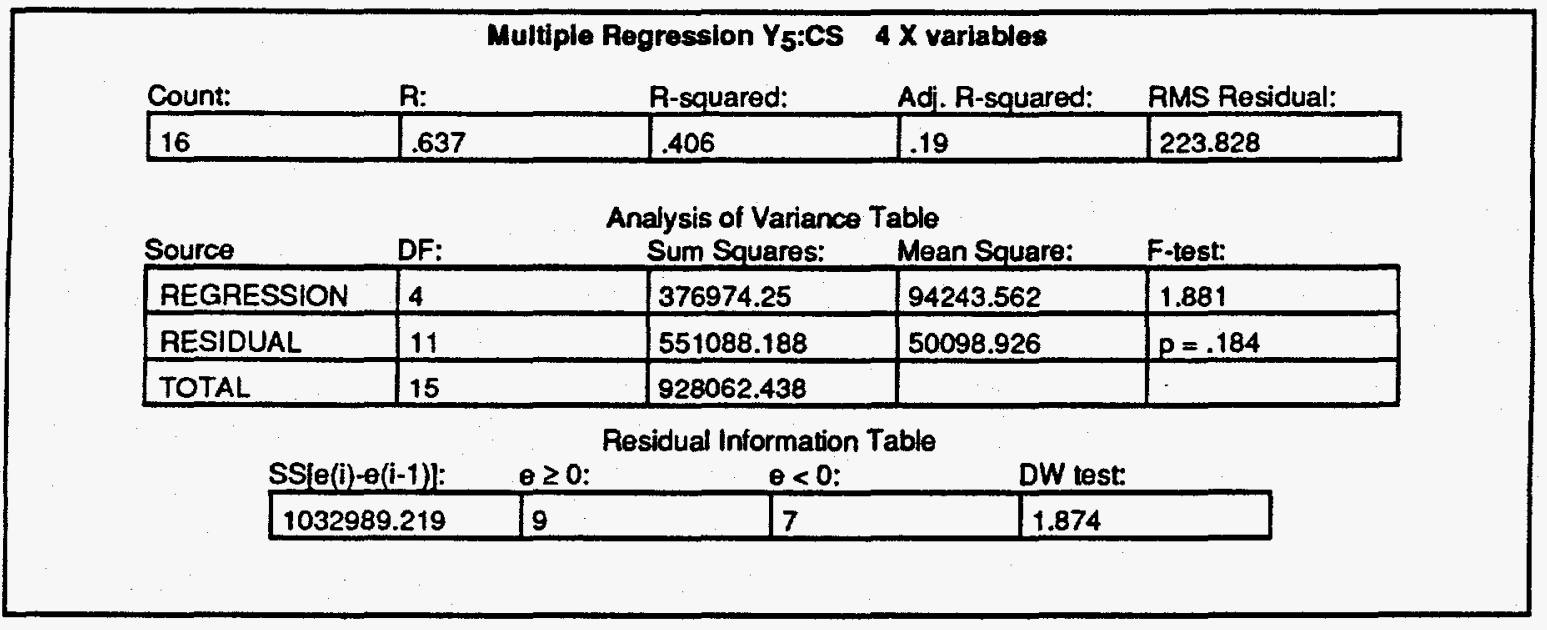

\begin{tabular}{|c|c|c|c|c|c|}
\hline \multicolumn{6}{|c|}{ Multiple Regression $Y_{5}: C S 4 X$ variables } \\
\hline \multicolumn{6}{|c|}{ Beta Coefficient Table } \\
\hline Variable: & Coefficient: & Std. Err.: & Std. Coeff.: & t-Value: & Probability: \\
\hline INTERCEPT & 881.281 & & & & \\
\hline F/C & -27.766 & 13.989 & -.461 & 1.985 & .0727 \\
\hline $\mathrm{s} / \mathrm{C}$ & 11.359 & 13.989 & .189 & .812 & .434 \\
\hline Dil & .047 & 1.13 & .01 & .041 & .9678 \\
\hline Temp & -4.784 & 2.798 & -.397 & 1.71 & .1153 \\
\hline
\end{tabular}

\begin{tabular}{|c|c|c|c|c|c|}
\hline \multicolumn{6}{|c|}{ Multiple Regression $Y_{5}: C S 4 X$ variables } \\
\hline \multicolumn{6}{|c|}{ Confidence Intervals and Partial F Table } \\
\hline Variable: & 95\% Lower: & $95 \%$ Upper: & $90 \%$ Lower: & $90 \%$ Upper: & Partial F: \\
\hline \multicolumn{6}{|l|}{ INTERCEPT } \\
\hline F/C & -58.559 & 3.028 & -52.891 & -2.64 & 3.939 \\
\hline S/C & -19.434 & 42.153 & -13.766 & 36.485 & .659 \\
\hline Dil & -2.442 & 2.535 & -1.984 & 2.077 & .002 \\
\hline Temp & -10.943 & 1.374 & -9.81 & .241 & 2.924 \\
\hline & $-\quad-$ & & & & \\
\hline
\end{tabular}

IABLE A5. Multiple Regression Analysis for Compressive Strength for the Matrix-1 Grout Samples 


\begin{tabular}{|c|c|c|c|c|c|}
\hline \multicolumn{6}{|c|}{ Multiple Regression $Y_{6}$ :Density $4 X$ variables } \\
\hline Count: & \multicolumn{2}{|l|}{ R: } & R-squared: & Adj. R-squared: & RMS Residual \\
\hline 16 & .772 & & .596 & .45 & .048 \\
\hline \multicolumn{6}{|c|}{ Analysis of Variance Table } \\
\hline REGRESSION & 4 & & .038 & .01 & 4.063 \\
\hline RESIDUAL & 11 & & .026 & .002 & $p=.0291$ \\
\hline TOTAL & 15 & & .064 & & \\
\hline \multicolumn{6}{|c|}{$\begin{array}{c}\text { Residual Information Table } \\
\theta \geq 0: \quad \theta<0: \\
\end{array}$} \\
\hline \multicolumn{2}{|l|}{.055} & 9 & 7 & 2.136 & \\
\hline
\end{tabular}

\begin{tabular}{|c|c|c|c|c|c|}
\hline \multicolumn{6}{|c|}{ Multiple Regression $Y_{6}:$ Density $4 X$ variables } \\
\hline \multicolumn{6}{|c|}{ Beta Coefficient Table } \\
\hline Variable: & Coefficient: & Sid. Enr: & Std. Coeff.: & t-Value: & Probability: \\
\hline INTERCEPT & 1.737 & & & & \\
\hline F/C &. .002 & .003 &. .103 & .536 & .6025 \\
\hline S/C & -.01 & .003 & -.608 & 3.176 & .0088 \\
\hline Dil &. .001 & $2.449 E-4$ &. .464 & 2.423 & .0338 \\
\hline Temp & 4.375E-5 & .001 & .014 & .072 & .9438 \\
\hline
\end{tabular}

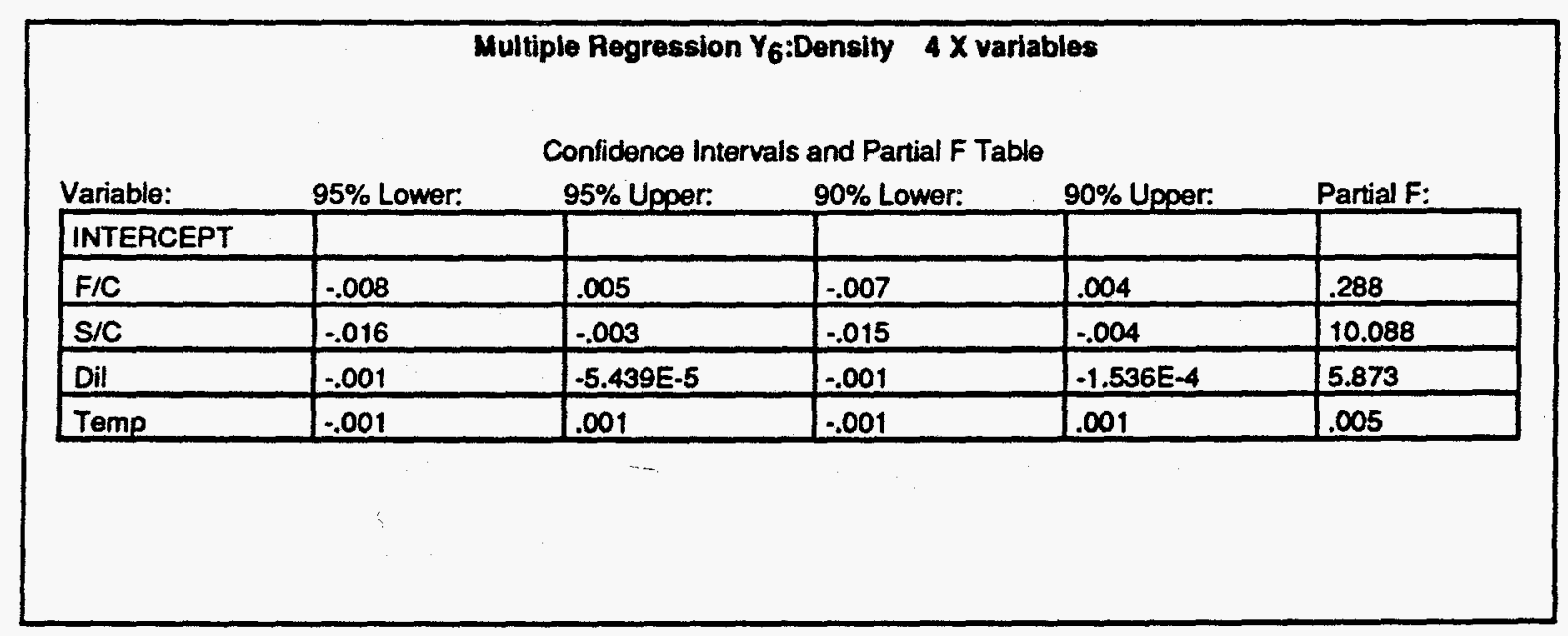

IABLEA6. Multiple Regression Analysis for Bulk Density for the Matrix-1 Grout Samples 


\begin{tabular}{|c|c|c|c|c|c|}
\hline \multicolumn{6}{|c|}{ Multiple Regression $Y_{7}$ :Evaporable Water $4 X$ varlables } \\
\hline Count: & \multicolumn{2}{|l|}{ R: } & R-squared: & Adj. R-squared: & RMS Residual: \\
\hline 16 & .723 & & .523 & .35 & 2.56 \\
\hline \multicolumn{6}{|c|}{ Analysis of Variance Table } \\
\hline REGRESSION & 4 & & 79.122 & 19.78 & 3.018 \\
\hline RESIDUAL & 11 & & 72.087 & 6.553 & $p=.0659$ \\
\hline TOTAL & 15 & & 151.209 & & \\
\hline \multicolumn{6}{|c|}{ Residual information Table } \\
\hline \multicolumn{2}{|c|}{158.223} & 8 & 8 & \multicolumn{2}{|c|}{2.195} \\
\hline
\end{tabular}

\begin{tabular}{|c|c|c|c|c|c|}
\hline \multicolumn{6}{|c|}{ Multiple Regression Y7:Evaporable Water $4 X$ variables } \\
\hline \multicolumn{6}{|c|}{ Beta Coefficient Table } \\
\hline Variable: & Coefficient: & Std. Err.: & Sid. Coeff.: & t-Value: & Probability: \\
\hline INTERCEPT & 22.811 & & & & \\
\hline $\mathrm{F} / \mathrm{C}$ & .096 & .16 & .125 & .602 & .5597 \\
\hline $\mathrm{S} / \mathrm{C}$ & .448 & .16 & .583 & 2.801 & .0172 \\
\hline Dil & .025 & .013 & .408 & 1.961 & .0757 \\
\hline Temp & .005 & .032 & .03 & .146 & .8862 \\
\hline
\end{tabular}

\begin{tabular}{|c|c|c|c|c|c|}
\hline \multirow[b]{3}{*}{ Variable: } & \multicolumn{4}{|c|}{ Multiple Regression Y7:Evaporable Water $4 X$ variables } & \multirow[b]{3}{*}{ Partial F: } \\
\hline & & \multicolumn{3}{|c|}{ Confidence Intervals and Partial F Table } & \\
\hline & 95\% Lower: & 95\% Upper: & 90\% Lower: & $90 \%$ Upper: & \\
\hline INTERCEPT & & & & & \\
\hline $\mathrm{F} / \mathrm{C}$ & -.256 & .448 & -.191 & .384 & .362 \\
\hline$S / C$ & .096 & .8 & .161 & .735 & 7.845 \\
\hline Dil & -.003 & .054 & .002 & .049 & 3.845 \\
\hline Temp. & -.066 & .075 & -.053 & .062 & .021 \\
\hline
\end{tabular}

IABLEA7. Multiple Regression Analysis for Evaporable Water Content for the Matrix-1 Grout Samples 


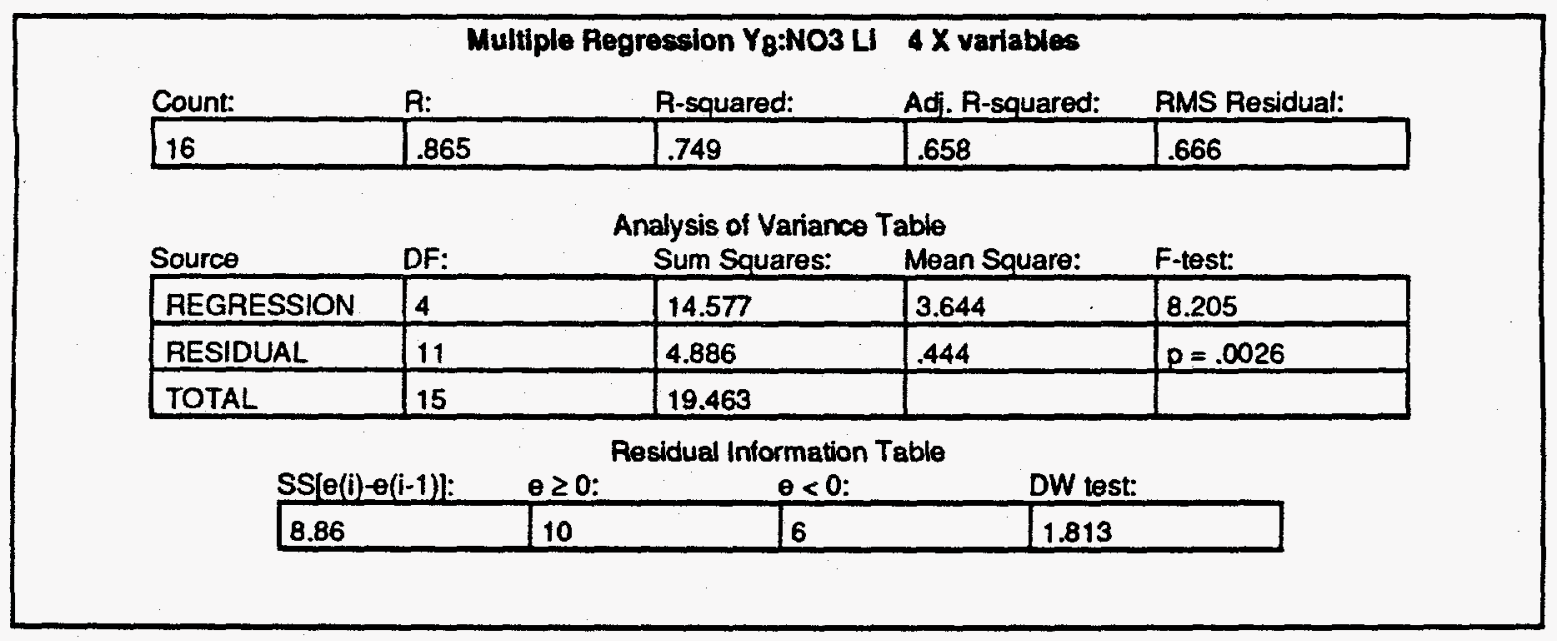

\begin{tabular}{|c|c|c|c|c|c|}
\hline \multicolumn{6}{|c|}{ Multiple Regression Yg:NO3 LI 4 X variables } \\
\hline Variable: & Coetficient: & Std. Err.: & Std. Coeff.: & t-Value: & Probability: \\
\hline INTEACEPT & 7.06 & & & & \\
\hline F/C & -.001 & .042 & -.005 & .034 & .9737 \\
\hline S/C & .168 & .042 & .608 & 4.025 & .002 \\
\hline Dil & .012 & .003 & .558 & 3.695 & .0035 \\
\hline Temp & -.014 & .008 & .26 & 1.722 & .1131 \\
\hline
\end{tabular}

\begin{tabular}{|c|c|c|c|c|c|}
\hline \multicolumn{6}{|c|}{ Multiple Regression Y 8 :NO3 LI 4 X variables } \\
\hline \multicolumn{6}{|c|}{ Confidence Intervals and Partial F Table } \\
\hline Variable: & 95\% Lower: & 95\% Upper: & 90\% Lower: & $90 \%$ Upper: & Partial F: \\
\hline \multicolumn{6}{|l|}{ INTERCEPT } \\
\hline$F / C$ & -.093 & .09 & -.076 & .073 & .001 \\
\hline S/C & .076 & .259 & .093 & .242 & 16.201 \\
\hline Dil & .005 & .02 & .006 & .018 & 13.653 \\
\hline Temp & -.033 & .004 &. .029 & .001 & 2.965 \\
\hline
\end{tabular}

IABLE A8. Multiple Regression Analysis for Nitrate Leachability Index for the Matrix-1 Grout Samples 


\begin{tabular}{|c|c|c|c|c|c|}
\hline \multicolumn{6}{|c|}{ Multiple Regression Yg:Na L $4 X$ variables } \\
\hline Count: & R: & & R-squared: & Adj. R-squared: & RMS Residual: \\
\hline 16 & .913 & & .833 & .773 & .583 \\
\hline \multicolumn{6}{|c|}{ Analysis of Variance Table } \\
\hline REGRESSION & 4 & & 18.653 & 4.663 & 13.743 \\
\hline RESIDUAL & 11 & & 3.732 & .339 & $p=.0003$ \\
\hline TOTAL & 15 & & 22.385 & & \\
\hline \multicolumn{6}{|c|}{ Residual Information Table } \\
\hline \multicolumn{2}{|l|}{5.114} & 9 & 7 & \multicolumn{2}{|l|}{1.37} \\
\hline
\end{tabular}

\begin{tabular}{|c|c|c|c|c|c|}
\hline \multirow[b]{2}{*}{ Variable: } & \multicolumn{4}{|c|}{ Multiple Regression Yg:Na Ll $4 X$ variables } & \multirow[b]{2}{*}{ Probability: } \\
\hline & Coefficient: & Std. Err.: & Std. Coeff.: & t-Value: & \\
\hline INTERCEPT & 6.971 & & & & \\
\hline$F / C$ & .111 & .036 & .376 & 3.051 & .011 \\
\hline S/C & .158 & .036 & .535 & 4.348 & .0012 \\
\hline Dil & .014 & .003 & .572 & 4.648 & .0007 \\
\hline Temp & -.017 & .007 &. .28 & 2.27 & .0443 \\
\hline
\end{tabular}

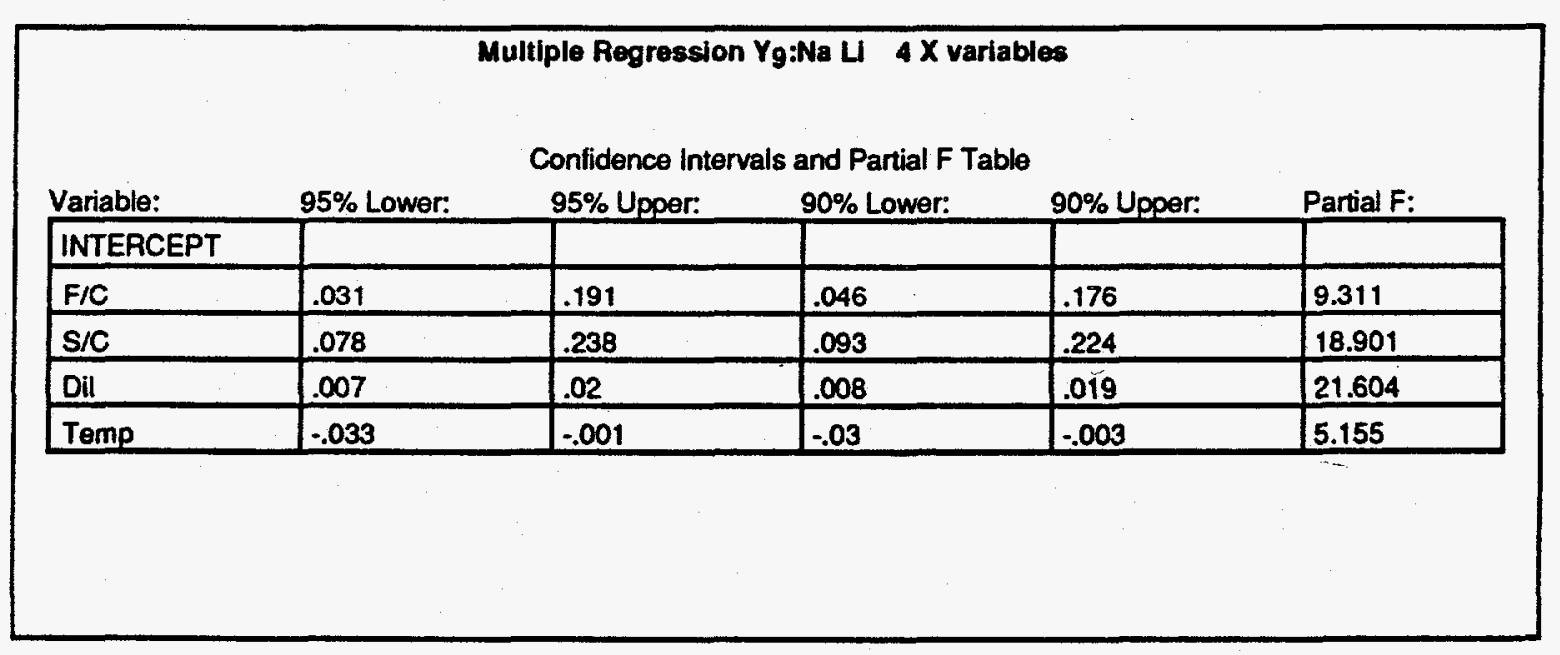

IABLE A9. Multiple Regression Analysis for Sodium Leachability Index for the Matrix-1 Grout Samples 


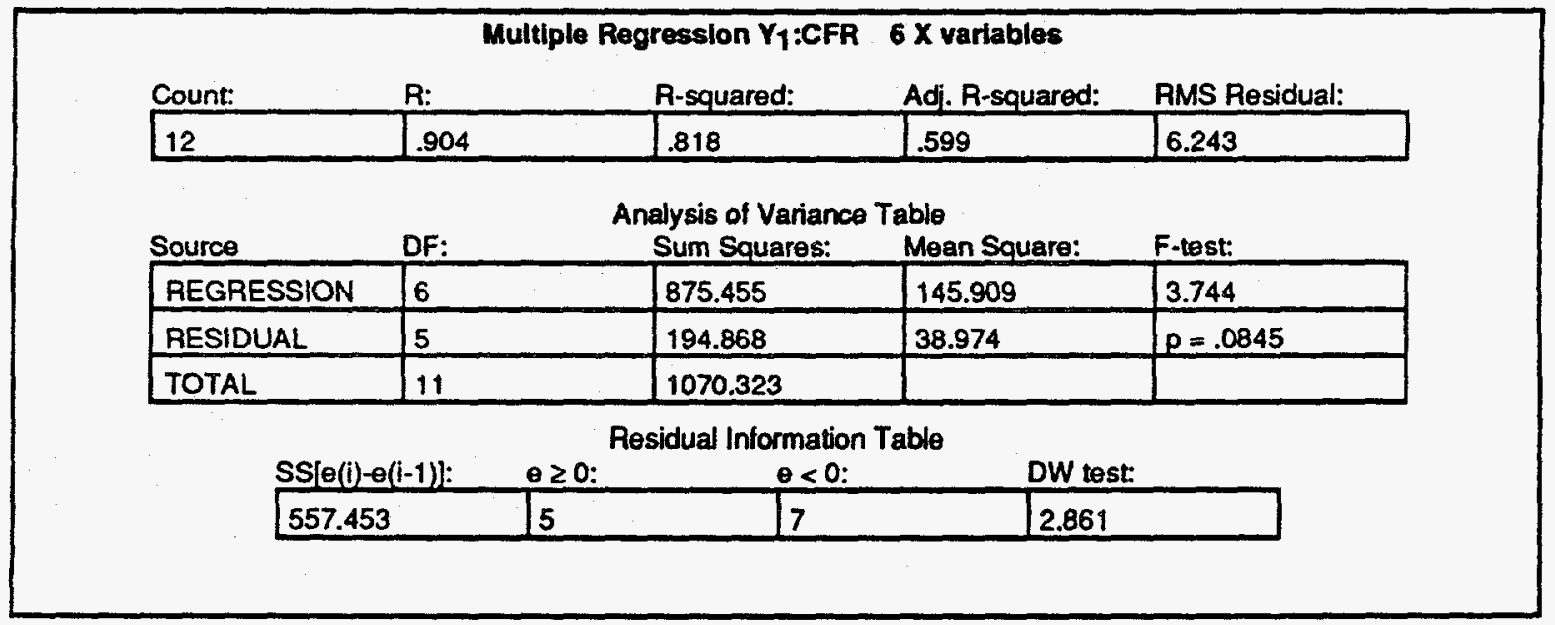

\begin{tabular}{|c|c|c|c|c|c|}
\hline \multicolumn{6}{|c|}{ Multiple Regression $Y_{1}:$ CFA $6 x$ variables } \\
\hline Variable: & Coefficient: & Sid. Err.: & Sid. Coetf.: & t-Value: & Probability: \\
\hline INTERCEPT & 30.84 & & & & \\
\hline Fly Ash/Cement & -1.742 & .451 &. .738 & 3.867 & .0118 \\
\hline Slag/Cement & .628 & .487 & .266 & 1.29 & .2533 \\
\hline Limestone & -.219 & .11 & -.463 & 1.983 & .1042 \\
\hline Water & .274 & .389 & .145 & .704 & .5131 \\
\hline Temperature & .029 & .097 & .061 & .296 & .7795 \\
\hline Time & -1.32 & 1.802 & -.14 & .732 & .4968 \\
\hline
\end{tabular}

\begin{tabular}{|c|c|c|c|c|c|}
\hline \multirow{2}{*}{\multicolumn{6}{|c|}{$\begin{array}{l}\text { Multiple Regression } \mathrm{Y}_{1} \text { :CFR } 6 \times \text { variables } \\
\text { Confidence Intervals and Partial F Table }\end{array}$}} \\
\hline & & & & & \\
\hline Variable: & 95\% Lower: & 95\% Upper: & $90 \%$ Lower: & $90 \%$ Upper. & Partial F: \\
\hline \multicolumn{6}{|l|}{ INTERCEPT } \\
\hline Fly Ash/Cement & -2.9 & -.584 & -2.65 & -.834 & 14.951 \\
\hline Slag/Cement & -.623 & 1.879 & -.353 & 1.609 & 1.665 \\
\hline Limestone & -.503 & .065 &. .441 & .004 & 3.93 \\
\hline Water & -.727 & 1.275 & -.511 & 1.059 & .495 \\
\hline Temperature &. .221 & .279 & -.167 & .225 & .087 \\
\hline Time & -5.953 & 3.313 & -4.952 & 2.312 & .536 \\
\hline
\end{tabular}

IABLE A10. Multiple Regression Analysis for Critical Flow Rate for the Matrix-2 Grout Samples 


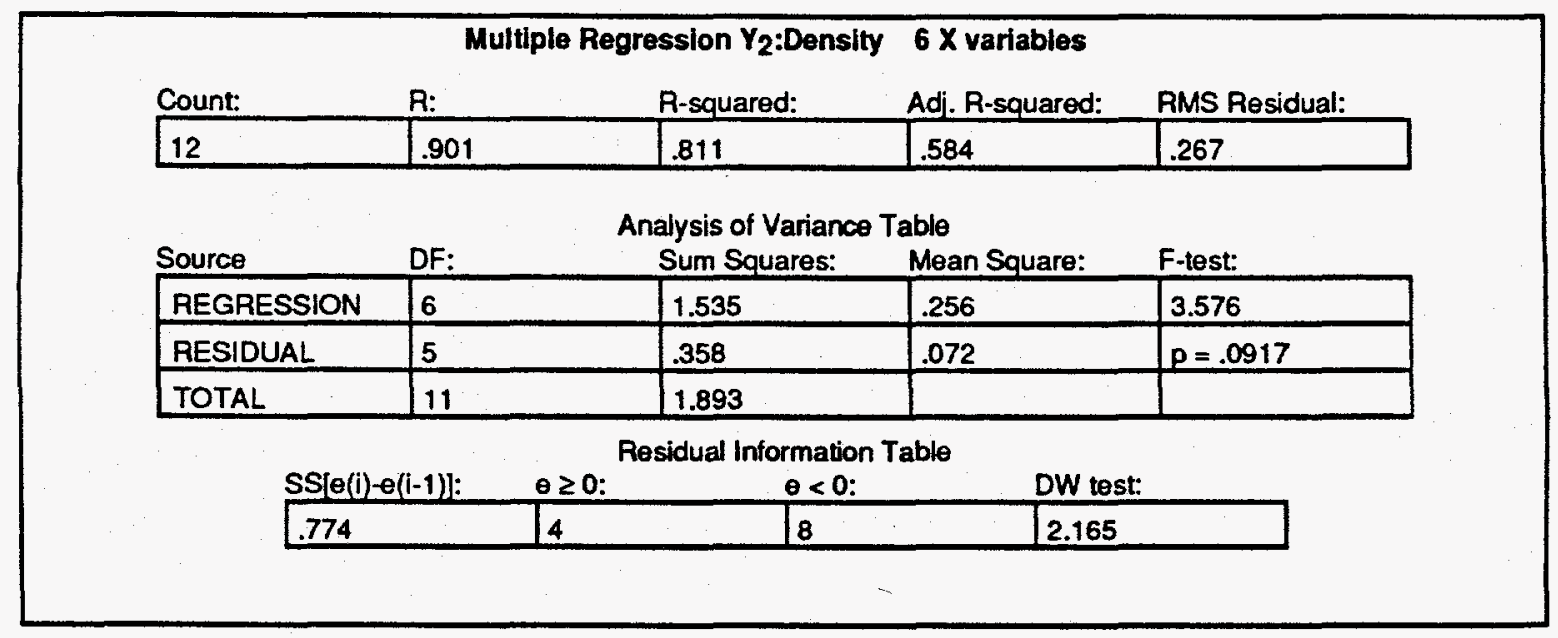

\begin{tabular}{|c|c|c|c|c|c|}
\hline \multicolumn{6}{|c|}{$\begin{array}{l}\text { Multiple Regression } Y_{2} \text { :Density } 6 \times \text { vartables } \\
\text { Bela Coefficient Table }\end{array}$} \\
\hline Variable: & Coefficient: & Std. Err.: & Std. Coeff.: & t-Value: & Probability \\
\hline INTERCEPT & 14.826 & & & & \\
\hline Fly Ash/Cement & -.085 & .019 & -.86 & 4.425 & .0069 \\
\hline Slag/Cement & .003 & .021 & .032 & .153 & .8842 \\
\hline Limestone & .001 & .005 & .067 & .282 & .7893 \\
\hline Water & -.006 & .017 & -.078 & .373 & .7244 \\
\hline Temperature & -.003 & .004 &. .148 & .706 & .5117 \\
\hline Time & -.078 & .077 & -.197 & 1.015 & .3569 \\
\hline
\end{tabular}

\begin{tabular}{|c|c|c|c|c|c|}
\hline \multicolumn{6}{|c|}{ Multiple Regression $Y_{2}$ :Density $6 X$ variables } \\
\hline Variable: & $95 \%$ Lower: & 95\% Upper: & $90 \%$ Lower: & 90\% Upper: & Partial F: \\
\hline \multicolumn{6}{|l|}{ INTERCEPT } \\
\hline Fly Ash/Cement & -.135 & .036 & -.124 & -.047 & 19.581 \\
\hline Slaq/Cement & -.05 & .057 & -.039 & .045 & .023 \\
\hline Limestone & -.011 & .013 & -.008 & .011 & .08 \\
\hline Water &. .049 & .037 & -.04 & .027 & .139 \\
\hline Temperature & -.014 & .008 & -.011 & .005 & .499 \\
\hline Time & -.277 & .12 &. .234 & .077 & 1.029 \\
\hline
\end{tabular}

\footnotetext{
IABLEA11. Multiple Regression Analysis for Slurry Density for the Matrix-2 Grout Samples
} 


\begin{tabular}{|l|l|l|l|l|}
\hline Count: & R: & R-squared: & Adj.R-squared: & RMS Residual: \\
\hline 12 & .877 & .769 & .491 & 345.217 \\
\hline
\end{tabular}

\begin{tabular}{|c|c|c|c|c|}
\hline \multicolumn{5}{|c|}{ Analysis of Variance Table } \\
\hline Source & DF: & Sum Squares: & Mean Square: & F-test: \\
\hline REGRESSION & 6 & 1979014.472 & 329835.745 & 2.768 \\
\hline RESIDUAL & 5 & 595874.444 & 119174.889 & $p=.1418$ \\
\hline TOTAL & 11 & 2574888.917 & & \\
\hline
\end{tabular}

Residual Information Table

\begin{tabular}{|l|l|l|l|} 
SS $(\theta(i)-\theta(i-1)]:$ & $\theta \geq 0:$ & $\theta<0:$ & DW test: \\
\hline 1246874.015 & 6 & 6 & 2.093 \\
\hline
\end{tabular}

\begin{tabular}{|c|c|c|c|c|c|}
\hline \multicolumn{6}{|c|}{ Multiple Regression $Y_{3}:$ Compressive Strength $6 \times$ variables } \\
\hline \multicolumn{6}{|c|}{ Beta Coefficient Table } \\
\hline Variable: & Coefficient: & Sid. Err: & Sid. Coeff.: & t-Value: & Probability: \\
\hline INTERCEPT & 1086.417 & & & & \\
\hline Fly Ash/Cement & 27.688 & 24.914 & .239 & 1.111 & .317 \\
\hline Slag/Cement & 21.569 & 26.91 & .186 & .802 & .4592 \\
\hline Limestone & -19.204 & 6.103 & -.829 & 3.147 & .0255 \\
\hline Water & 6.578 & 21.528 & .071 & .306 & .7723 \\
\hline Temperature & -1.744 & 5.382 & -.075 & .324 & .759 \\
\hline Time & 11.25 & 99.656 & .024 & .113 & .9145 \\
\hline
\end{tabular}

\begin{tabular}{|c|c|c|c|c|c|}
\hline \multicolumn{6}{|c|}{$\begin{array}{c}\text { Multiple Regression } Y_{3} \text { :Compressive Strength } 6 \times \text { variables } \\
\text { Confidence Intervals and Partial F Table }\end{array}$} \\
\hline Variable: & 95\% Lower: & 95\% Upper: & 90\% Lower: & $90 \%$ Upper: & Partial F: \\
\hline \multicolumn{6}{|l|}{ INTERCEPT } \\
\hline Fly Ash/Cement & -36.365 & 91.74 & -22.521 & 77.896 & 1.235 \\
\hline Slag/Cement & -47.615 & 90.754 & -32.662 & 75.801 & .642 \\
\hline Limestone & -34.894 & -3.515 & -31.503 & -6.906 & 9.903 \\
\hline Water & -48.77 & 61.925 & -36.808 & 49.963 & .093 \\
\hline Temperature & -15.581 & 12.092 & -12.591 & 9.102 & .105 \\
\hline Time & -244.96 & 267.46 & -189.585 & 212.085 & .013 \\
\hline
\end{tabular}

IABLE A12. Multiple Regression Analysis for Compressive Strength for the Matrix-2 Grout Samples 


\begin{tabular}{|c|c|c|c|c|c|}
\hline \multicolumn{6}{|c|}{ Multiple Regression $Y_{4}$ :Bulk Density $6 X$ variables } \\
\hline Count: & \multicolumn{2}{|l|}{ R: } & R-squared: & Adj. R-squared: & RMS Residual: \\
\hline 12 & .885 & & .784 & .524 & .032 \\
\hline \multicolumn{6}{|c|}{ Analysis of Variance Table } \\
\hline REGRESSION & 6 & & .019 & .003 & 3.017 \\
\hline RESIDUAL & 5 & & .005 & .001 & $p=.123$ \\
\hline TOTAL & 11 & & .024 & & \\
\hline \multicolumn{6}{|c|}{$\theta<0: \quad \begin{array}{c}\text { Residual Information Table } \\
\theta<0:\end{array}$} \\
\hline \multicolumn{2}{|l|}{.011} & 4 & 8 & \multicolumn{2}{|l|}{2.137} \\
\hline
\end{tabular}

\begin{tabular}{|c|c|c|c|c|c|}
\hline \multicolumn{6}{|c|}{ Multiple Regression $Y_{4}$ :Bulk Density $6 \times$ variables } \\
\hline \multicolumn{6}{|c|}{ Beta Coefficient Table } \\
\hline Variable: & Coefficient: & Sid. Err.: & Std. Coeff:: & t-Value: & Probability: \\
\hline INTERCEPT & 1.761 & & & & \\
\hline Fly Ash/Cement & -.009 & .002 & -.847 & 4.069 & .0096 \\
\hline Slag/Cement & -.001 & .003 & -.06 & .267 & .8001 \\
\hline Limestone & $3.042 E-4$ & .001 & .136 & .532 & .6176 \\
\hline Water & -.001 & .002 & -.1 & .443 & .676 \\
\hline Temperature & $-1.514 E-4$ & .001 & -.067 & .3 & .7761 \\
\hline Time & -.008 & .009 &. .182 & .874 & .4219 \\
\hline
\end{tabular}

\begin{tabular}{|c|c|c|c|c|c|}
\hline \multicolumn{6}{|c|}{ Multiple Regression $Y_{4}:$ Bulk Density $6 X$ variables } \\
\hline Variable: & 95\% Lower: & 95\% Upper: & 90\% Lower: & 90\% Upper: & Partial F: \\
\hline INTERCEPT & & & & & \\
\hline Fly Ash/Cement & -.016 & -.003 & -.014 & -.005 & 16.556 \\
\hline Slag/Cement & -.007 & .006 & -.006 & .004 & .071 \\
\hline Limestone & -.001 & .002 & -.001 & .001 & .283 \\
\hline Water & -.006 & .004 & -.005 & .003 & .197 \\
\hline Temperature & -.001 & .001 & -.001 & .001 & .09 \\
\hline Time & -.032 & .016 & -.027 & .011 & .765 \\
\hline
\end{tabular}

IABLE A13. Multiple Regression Analysis for Bulk Density for the Matrix-2 Grout Samples 


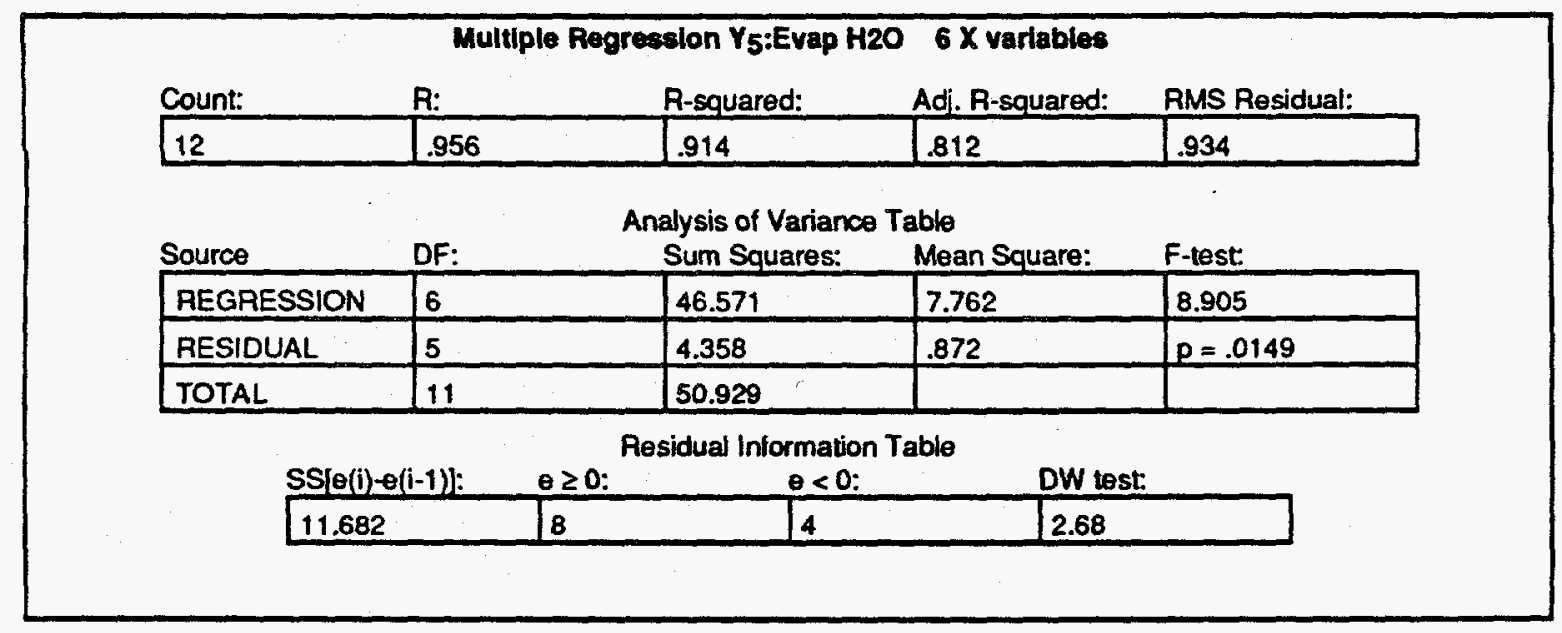

\begin{tabular}{|c|c|c|c|c|c|}
\hline \multicolumn{6}{|c|}{ Multiple Regression Y5:Evap H2O 6 X variables } \\
\hline Variable: & Coefficient: & Std. Err.: & Std. Coetf.: & t-Value: & Probability: \\
\hline INTERCEPT & 29.044 & & & & \\
\hline Fly Ash/Cement & .465 & .067 & .902 & 6.895 & .001 \\
\hline Slag/Cement &. .06 & .073 & -.117 & .83 & .4443 \\
\hline Limestone & .03 & .017 & .291 & 1.818 & .1288 \\
\hline Water & .012 & .058 & .028 & .2 & .8491 \\
\hline Temperature & .009 & .015 & .085 & .601 & .574 \\
\hline Time & .158 & .27 & .077 & .587 & .5824 \\
\hline
\end{tabular}

\begin{tabular}{|c|c|c|c|c|c|}
\hline \multicolumn{6}{|c|}{ Multiple Regression $\mathrm{Y}_{5}$ :Evap $\mathrm{H}_{2} \mathrm{O} \quad 6 \times$ variables } \\
\hline \multicolumn{6}{|c|}{ Confidence Intervals and Partial F Table } \\
\hline Variable: & 95\% Lower: & 95\% Upper: & 90\% Lower: & $90 \%$ Upper: & Partial F: \\
\hline \multicolumn{6}{|l|}{ INTERCEPT } \\
\hline Fly Ash/Cement & .291 & .638 & .329 & .6 & 47.542 \\
\hline Slag/Cement &. .248 & .127 & -.207 & .086 & .689 \\
\hline Limestone & -.012 & .072 & -.003 & .063 & 3.304 \\
\hline Water & -.138 & .161 & -.106 & .129 & .04 \\
\hline Temperature & -.029 & .046 &. .021 & .038 & .361 \\
\hline Time & -.535 & .851 & -.385 & .701 & .345 \\
\hline
\end{tabular}

IABLE A14. Multiple Regression Analysis for Evaporable Water Content for the Matrix-2 Grout Samples 


\begin{tabular}{|c|c|c|c|c|c|}
\hline \multicolumn{6}{|c|}{ Multiple Regression $Y_{6}: \mathrm{NO}^{2} \mathrm{LI} \quad 6$ X varlables } \\
\hline Count: & R: & & R-squared: & Adj. R-squared: & RMS Residual: \\
\hline 12 & .936 & & .877 & .729 & .369 \\
\hline \multicolumn{6}{|c|}{$\begin{array}{l}\text { Analysis of Variance Table } \\
\text { Sum Squares: Mean Square: }\end{array}$} \\
\hline REGRESSION & 6 & & 4.862 & .81 & 5.941 \\
\hline RESIDUAL & 5 & & .682 & .136 & $p=.0348$ \\
\hline TOTAL & 11 & & 5.543 & & \\
\hline \multicolumn{6}{|c|}{ Residual Information Table } \\
\hline \multicolumn{2}{|l|}{1.87} & 6 & 6 & \multicolumn{2}{|c|}{2.742} \\
\hline
\end{tabular}

\begin{tabular}{|c|c|c|c|c|c|}
\hline \multirow{2}{*}{\multicolumn{6}{|c|}{$\begin{array}{c}\text { Multiple Regression } \mathrm{Y}_{6}: \mathrm{NO} 3 \mathrm{LI} \quad 6 \mathrm{X} \text { variables } \\
\text { Beta Coefficient Table }\end{array}$}} \\
\hline & & & & & \\
\hline Variable: & Coefficient: & Sid. Err.: & Std. Coeff.: & t-Value: & Probability: \\
\hline INTERCEPT & 8.769 & & & & \\
\hline Fly Ash/Cement & .07 & .027 & .412 & 2.627 & .0467 \\
\hline Slag/Cement & .03 & .029 & .176 & 1.037 & .3471 \\
\hline Limesione & .008 & .007 & -.248 & 1.289 & .2537 \\
\hline Water & $4.444 E-4$ & .023 & .003 & .019 & .9853 \\
\hline Temperature & .023 & .006 & -.665 & 3.927 & .0111 \\
\hline Time & -.205 & .107 & -.302 & 1.923 & .1125 \\
\hline
\end{tabular}

\begin{tabular}{|c|c|c|c|c|c|}
\hline \multicolumn{6}{|c|}{ Multiple Regression $Y_{6}: N O 3 L 6$ X variables } \\
\hline Variable: & 95\% Lower: & 95\% Upper: & 90\% Lower: & 90\% Upper: & Partial F: \\
\hline \multicolumn{6}{|l|}{ INTERCEPT } \\
\hline Fly Ash/Cement & .001 & .139 & .016 & .124 & 6.899 \\
\hline Slag/Cement & -.044 & .104 & -.028 & .088 & 1.076 \\
\hline Limestone & -.025 & .008 & -.022 & .005 & 1.662 \\
\hline Water & -.059 & .06 & -.046 & .047 & $3.725 E-4$ \\
\hline Temperature & .037 & .008 & .034 & -.011 & 15.424 \\
\hline Time & -.479 & .069 & -.42 & .01 & 3.698 \\
\hline
\end{tabular}

IABLE A15. Multiple Regression Analysis for Nitrate Leachability Index for the Matrix-2 Grout Samples 


\begin{tabular}{|c|c|c|c|c|c|}
\hline \multicolumn{6}{|c|}{ Multiple Regression $Y_{7}: \mathrm{Na}$ LI $6 \times$ variables } \\
\hline Count: & \multicolumn{2}{|l|}{$\mathrm{R}:$} & R-squared: & Ad]. R-squared: & RMS Residual: \\
\hline 12 & .961 & & .923 & .831 & .301 \\
\hline \multicolumn{6}{|c|}{ Analysis of Variance Table } \\
\hline REGRESSION & 6 & & 5.476 & .913 & 10.044 \\
\hline RESIDUAL & 5 & & .454 & .091 & $p=.0114$ \\
\hline TOTAL & 11 & & 5.93 & & \\
\hline \multicolumn{6}{|c|}{ Residual Information Table } \\
\hline \multicolumn{2}{|c|}{1.316} & 6 & 6 & \multicolumn{2}{|c|}{2.896} \\
\hline
\end{tabular}

\begin{tabular}{|c|c|c|c|c|c|}
\hline & & $\begin{array}{r}\text { Iple Regre: } \\
\mathrm{Be}\end{array}$ & $\begin{array}{l}\text { : Na LI } 6 \times 1 \\
\text { cient Table }\end{array}$ & & \\
\hline Variable: & Coefficient: & Std. Err: & Std. Coeff.: & t-Value: & Probability: \\
\hline INTERCEPT & 8.108 & & & & \\
\hline Fly Ash/Cement & .117 & .022 & .664 & 5.363 & .003 \\
\hline Slag/Cement & .026 & .023 & .146 & 1.091 & .3252 \\
\hline Limestone & -.009 & .005 & -.267 & 1.759 & .1388 \\
\hline Water & .014 & .019 & .098 & .736 & .4948 \\
\hline Temperature & .019 & .005 & -.528 & 3.945 & .0109 \\
\hline Time & -.092 & .087 & -.13 & 1.053 & .3404 \\
\hline
\end{tabular}

\begin{tabular}{|c|c|c|c|c|c|}
\hline \multicolumn{6}{|c|}{$\begin{array}{c}\text { Multiple Regression } Y_{7}: \text { Na } L \quad 6 \times \text { variables } \\
\text { Confidence Intervals and Partial F Table }\end{array}$} \\
\hline Variable: & 95\% Lower: & 95\% Upper: & $90 \%$ Lower: & 90\% Upper: & Partial F: \\
\hline \multicolumn{6}{|l|}{ INTERCEPT } \\
\hline Fly Ash/Cement & .061 & .173 & .073 & .161 & 28.761 \\
\hline Slag/Cement & -.035 & .086 & -.022 & .073 & 1.189 \\
\hline Limestone &. .023 & .004 & -.02 & .001 & 3.095 \\
\hline Water & -.034 & .062 & -.024 & .052 & .542 \\
\hline Temperature & -.031 &. .006 & -.028 & -.009 & 15.567 \\
\hline Time & -.315 & .132 & -.267 & .084 & 1.11 \\
\hline
\end{tabular}

IABLE A16. Multiple Regression Analysis for Sodium Leachability Index for the Matrix-2 Grout Samples 


\section{DISTRIBUTION}

No. of

Copies

QFESITE

2 DOE/Office of Scientific and Technical Information

2 Westinghouse Savannah River Company

Savannah River Site

Aiken, SC 29808-0001

ATTN: C. A. Langton

M. Hay

2 Oak Ridge National Laboratory

P.0. Box $X$

Oak Ridge, TN 37831

ATTN: E. W. MCDaniel

R. D. Spence
No. of

Copies

29

Pacific Northwest Laboratory

L. M. Bagassen

K. A. Borgeson

R. E. Einziger

D. K. Kried

R. 0. Lokken (5)

P. F. C. Martin

J. L. McElroy

G. L. McVay

R. K. Quinn

P. A. Scott

R. J. Serne

P. Sliva

J. H. Westsik, Jr. (5)

G. A. Whyatt

K. D. Wiemers

Publishing Coordination

Technical Report Files (5)

\section{ONSITE}

3

DOE Richland Field office

K. W. Bracken

G. H. Sanders

L. A. Huffman

19 Westinghouse Hanford Company

K. W. Bledsoe

J. M. Connor

J. L. Epstein

A. P. Hammitt

D. W. Hendrickson

A. A. Kruger

D. J. Newl and

W. J. Powel1

T. V. Rebagay

E. F. Riebling

J. L. Scott

J. W. Shade

J. E. Van Beek

J. A. Voogd (4)

T. L. Welsh

G. F. Williamson 